\title{
Manifestações Públicas Em Tempos Pandêmicos: Efeitos Da Covid-19 Na Positivação Infraconstitucional Do Direito De Reunião
}

\author{
Tiago Cisneiros Barbosa de Araújo * \\ Universidade Católica de Pernambuco, Programa de Pós-Graduação em Direito, Recife-PB, Brasil. \\ iD https://orcid.org/oooo-0002-7254-7342 \\ Bruno Galindo ** \\ Universidade Federal de Pernambuco, Programa de Pós-Graduação em Direito, Recife-PB, Brasil.
} iD https://orcid.org/0000-0002-8787-4119

\begin{abstract}
Resumo: O artigo aborda as tentativas de regulamentação infraconstitucional do direito de reunião no Brasil, em meio à pandemia de covid-19. Empreende-se a análise da situação, a partir da crise sanitária e das disputas político-ideológicas, com foco na atuação do Legislativo Federal. O objetivo é verificar se os riscos do coronavírus motivaram a apresentação de propostas que estabelecessem mais regras ou limites ao exercício daquela liberdade fundamental. $\mathrm{O}$ artigo funda-se em pesquisa qualitativa, utilizando dados públicos, e está dividido em quatro partes. $\mathrm{Na}$ primeira, discutem-se conceito, disposições normativas e alcance do direito de reunião. A segunda seção contempla respostas do Executivo e do Judiciário acerca de manifestações no segundo trimestre de 2020, ante a pandemia e o caráter antidemocrático de alguns atos. Na terceira parte, realizam-se levantamento e análise de projetos sobre direito de reunião e suas justificativas, de modo a responder ao problema acerca da influência da covid-19. Por fim, abordam-se as soluções estatais à luz da eficácia e do conteúdo daquele direito, assim como das limitações a sua restrição. Como resultado, refuta-se a hipótese de pesquisa de que a pandemia estimularia tentativas de regulamentação da liberdade de reunião. Em regra, as propostas legislativas têm, como motivação, questões político-ideológicas.
\end{abstract}

Palavras-chave: Liberdade de reunião. Direitos fundamentais. Manifestações. Covid-19. Política. Antifa.

* Mestre em Processo na Universidade Católica de Pernambuco. E-mail: tiagocisneiros@gmail.com

** Professor Associado da Faculdade de Direito do Recife, Universidade Federal de Pernambuco (UFPE); Doutor em Direito pela UFPE/Universidade de Coimbra-Portugal (PDEE). E-mail: brunogalindoufpe@gmail.com

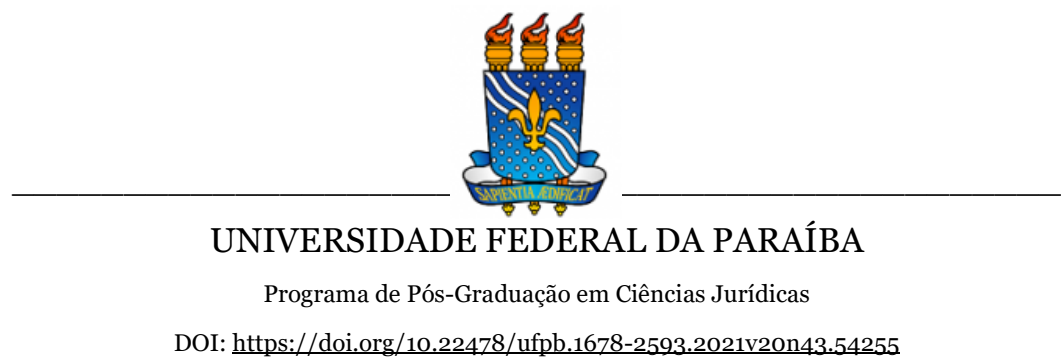




\title{
Manifestações Públicas Em Tempos Pandêmicos: Efeitos Da Covid-19 Na Positivação Infraconstitucional Do Direito De Reunião
}

Tiago Cisneiros Barbosa de Araújo

\author{
Bruno Galindo
}

\section{INTRODUÇÃO}

A pandemia de covid-19 fomentou tentativas de regulamentação infraconstitucional do direito de reunião no Brasil?

A pergunta que serve como ponto de partida deste artigo pode parecer descabida a um primeiro olhar. Mas não é. Tanto que se adota uma resposta provisória afirmativa, isto é, de que a pandemia motivou a apresentação de proposições legislativas visando a regulamentar o direito fundamental previsto no art. $5^{\circ}$, XVI, da Constituição da República de 1988. As justificativas, tanto para o problema de pesquisa, quanto para a hipótese, residem na experiência peculiar vivenciada no Brasil, a partir de março de 2020.

Concomitantemente à chegada e à disseminação da covid-19, o país mergulhou em intensas disputas sociais e políticas, atreladas a diversos fatores, como conflitos entre membros dos três poderes; divergências e desinformações relacionadas à enfermidade e a possíveis tratamentos; e episódios nacionais e estrangeiros relacionados à violência policial e ao racismo.

Essas disputas transpuseram os limites das redes sociais e alcançaram as ruas. Em um primeiro momento, sobretudo em Brasília e São Paulo, espaços públicos foram ocupados exclusivamente por grupos ligados ao presidente da República Jair Bolsonaro, em apoio as suas ideias e discursos, de viés negacionista em relação à ciência e à 
covid-19. Na pauta, pedidos de intervenção militar, fechamento de Congresso e Supremo Tribunal Federal, insurgência contra a imprensa e ex-aliados considerados traidores (como o ex-juiz e ex-ministro Sérgio Moro) e a defesa de remédios sem eficácia comprovada contra a doença, como é o caso da cloroquina (FERNANDES; PUPO, 2020; G1, 2020a; AMORIM; BORGES, 2020).

O monopólio das ruas somente foi rompido em 31 de maio de 2020, quando eclodiram as notícias das primeiras manifestações relevantes de grupos de oposição (VEJA, 2020), até então, ironicamente, dedicados a panelaços e protestos em redes sociais, estas últimas uma espécie de habitat dos apoiadores da atual gestão federal. O início desses protestos, contudo, não coincide com uma melhora na situação sanitária do país. Pelo contrário: nove dias antes dos atos, o Brasil assumira a segunda posição global no número de casos e, um dia antes, a quarta colocação no total de mortes (G1, 2020b).

As bandeiras das manifestações e os motivos pelos quais os grupos contrários ao presidente decidiram passar a dividir (ou disputar) as ruas com seus adversários políticos ilustram o cenário de fundo deste artigo, mas não são o seu objeto.

O cerne da abordagem é outro: a regulamentação infraconstitucional do direito de reunião, pretensamente exercido por ambos os lados nesses episódios. Afinal, tem-se a multiplicação de protestos presenciais em um quadro pandêmico, com uma doença transmitida pelo ar, sobretudo em aglomerações. A realização dessas manifestações, em contrariedade às orientações da Organização Mundial de Saúde (OMS) e da maioria das autoridades sanitárias, motivou proposições voltadas a restringir ou regulamentar essa liberdade?

A discussão ora proposta é desenvolvida ao longo de quatro seções, em uma abordagem que mescla a revisão de literatura, legislação e jurisprudência com um levantamento nos sítios oficiais da Câmara dos Deputados e do Senado Federal. 
Na primeira seção, discutiremos o conceito e as previsões normativas do direito de reunião no Brasil, útil como apresentação do estado da arte atual, isto é, como ponto de partida para o aprofundamento do debate e o diálogo com as proposições de alteração legal. Na segunda parte, serão descritas e analisadas medidas e respostas fornecidas pelos Executivos estadual e municipal, bem como pelo Judiciário, em relação ao exercício daquela liberdade, durante os primeiros meses da pandemia no país. Estabelece-se, ainda, um paralelo com as decisões do Tribunal Constitucional alemão, também provocado a responder sobre a possibilidade ou não de restringir aquele direito em meio à crise sanitária.

Na terceira seção, será realizado um levantamento de projetos em tramitação no Congresso Nacional propostos até junho de 2020, com vistas a regulamentar ou limitar o direito de reunião. A análise das propostas considerará também a pertinência com o momento político atual e com a pandemia de covid-19, a fim de responder à indagação central da pesquisa.

$\mathrm{Na}$ quarta e última parte, recorrem-se a bases e conceitos teórico-doutrinários, como a classificação dos direitos fundamentais de José Afonso da Silva (1993), o exame sistemático proposto por Leonardo Martins (2017), a teoria dos limites dos limites e a ideia de núcleo essencial. A partir deles, bem como da análise jurisprudencial do STF, propomos uma discussão com aspirações prospectivas, identificando as possíveis respostas judiciais, em sede de controle de constitucionalidade, na hipótese de aprovação e sanção das propostas legislativas de regulamentação da liberdade de reunião.

\section{DIREITO DE REUNIÃO: CONCEITO E PREVISÕES NORMATIVAS NO BRASIL}

A natureza do direito de reunião importa uma proximidade inevitável com a liberdade de expressão suscitando, por vezes, uma 
indevida confusão entre eles. Algumas notas distintivas, porém, permitem a compreensão adequada de seus conteúdos.

Para Sarlet e Neto (2017, p. 640-642), a liberdade de expressão constitui espécie de "direito mãe", que engloba a livre manifestação do pensamento prevista no art. $5^{\circ}$, IV, da Constituição da República (o qual reputam uma cláusula geral), mas também outras dimensões, como as liberdades de consciência e crença, de atividade intelectual, artística, científica e de comunicação, independentemente de censura ou licença. De forma mais precisa, os autores consideram que a liberdade de opinião - de exprimir juízos de valor e manifestações sobre fatos - está na base de todas as modalidades do direito.

Também nesse sentido, Simão e Rodovalho (2017, p. 209) conceituam a liberdade de expressão como "o poder conferido aos cidadãos para externar opiniões, ideias, convicções, juízos de valor, bem como sensações e sentimentos, garantindo-se, também, os suportes por meios dos quais a expressão é manifestada".

É aqui que entra o direito de reunião: como meio de manifestação da expressão. Pode-se compreendê-lo, especificamente, como forma de "manifestação coletiva da liberdade de expressão, exercitada por meio de uma associação transitória de pessoas e tendo por finalidade o intercâmbio de ideias, a defesa de interesses, a publicidade de problemas e de determinadas reivindicações" (MORAES, 2019, p. 36).

Essa manifestação, pontuam Dias e De Laurentiis (2015, p. 650), revela-se essencial, junto à liberdade de expressão, em uma democracia, na medida em que evita a visão absoluta da maioria como única definidora dos rumos da sociedade. $O$ direito de reunião confere às minorias a possibilidade de "se fazer ouvir com mais intensidade e, quem sabe, alcançar uma vitória democrática ou, até mesmo, se tornar maioria, sem que seja necessário derramamento de sangue”.

A modalidade tradicional desse direito é a passeata ou o protesto a pé, ainda que com os participantes reunidos em um só local, sem movimentação. Não há óbice, contudo, a seu exercício em outros 
formatos, como a realização de carreatas, o que, aliás, foi expressamente reconhecido, pelo Ministro Celso de Mello, do Supremo Tribunal Federal, já no cenário objeto deste artigo, qual seja, de manifestações políticas ocorridas no período da pandemia de covid19. Na decisão monocrática que negou conhecimento ao pedido de medida cautelar 8830/DF, ajuizado com o intuito de impedir um protesto com possíveis 300 caminhões em Brasília, o decano da Corte salientou:

Impõe-se, desse modo, ao Estado, em uma sociedade estruturada sob a égide de um regime democrático, o dever de respeitar a liberdade de reunião (de que são manifestações expressivas o comício, o desfile, a procissão, carreata, a marcha e a passeata), que constitui prerrogativa essencial dos cidadãos, normalmente temida pelos regimes despóticos ou ditatoriais, que não hesitam em golpeá-la, para asfixiar, desde logo, o direito de protesto, de crítica e de discordância daqueles que se opõem à prática autoritária do poder (BRASIL, 2020a, p. 7)

A decisão transcreve, também, o art. $5^{\circ}$, XVI, da Constituição, que estabelece o status de direito fundamental à liberdade de reunião, nos seguintes termos:

Art. $5^{\circ} \cdot[\ldots]$

XVI - todos podem reunir-se pacificamente, sem armas, em locais abertos ao público, independentemente de autorização, desde que não frustrem outra reunião anteriormente convocada para o mesmo local, sendo apenas exigido prévio aviso à autoridade competente; [...] (BRASIL, 1988)

O texto normativo, que guarda fortes semelhanças com as previsões das Constituições anteriores ${ }^{1}$, mas, também, com a atual Carta Maior portuguesa ${ }^{2}$, apresenta cinco requisitos para o exercício

${ }^{1}$ A primeira Constituição do país, de 1824 , não faz menção à liberdade de reunião. Desde 1891, contudo, todas as Cartas aludem a tal direito, tendo em comum os requisitos do caráter pacífico e da ausência de armas. Há, contudo, variação em relação ao alcance da intervenção estatal. O texto do Estado Novo, em 1937, permitia a proibição das reuniões "em caso de perigo imediato para a segurança pública", e a Constituição outorgada pelo regime militar, em 1967, previa que a lei poderia "determinar os casos em que será necessária a comunicação prévia à autoridade, bem como a designação, por esta, do local da reunião" (BRASIL, 1824; BRASIL, 1891; BRASIL, 1934; BRASIL, 1937; BRASIL, 1946; BRASIL, 1967). Para análise mais detalhada das previsões normativas em cada período: ARAÚJO, 2017, p. 40-44.

2 "Art. 45. 1. Os cidadãos têm o direito de se reunir, pacificamente e sem armas, mesmo em lugares abertos ao público, sem necessidade de qualquer autorização. 2. A todos os cidadãos é reconhecido o direito de manifestação." (PORTUGAL, 1976). 
do direito de reunião. Seriam eles: o caráter pacífico, a ausência de armas, o uso de local aberto ao público, a inexistência de reunião anteriormente convocada para o mesmo lugar e o aviso prévio à autoridade competente. Este último não se confunde com pedido de autorização, "o que implicaria na submissão desse direito a vontade do Poder Público o que é vedado pela Constituição” (NOVELLINO, 2017, p. 29).

Os três primeiros desses pressupostos também são identificados por Sousa (2012, p. 30-34) em relação ao art. 45, $1^{\circ}$, da Constituição da República Portuguesa, segundo o qual “[o]s cidadãos têm o direito de se reunir, pacificamente e sem armas, mesmo em lugares abertos ao público, sem necessidade de qualquer autorização" (PORTUGAL, 1976). Naquele país, a necessidade de aviso prévio às autoridades está prevista no Decreto-Lei $n^{0}$ 406/74, ou Lei das Reuniões. Porém, a sua inobservância, para o autor, não deve ser causa suficiente para a dissolução da reunião, inclusive por aquela exigência não fazer sentido na reunião espontânea (concentração espontânea, que evolui para manifestação), nem tem lugar na hipótese de reunião urgente, incompatível com o tempo regular do aviso prévio, de dois dias úteis (SOUSA, 2012, p. 37).

No Brasil, não existe diploma federal que regulamente 0 art. $5^{\circ}$, XVI, da Constituição. A Lei $n^{0} 1.207 / 1950$, promulgada quase quatro décadas antes, "dispõe sobre o direito de reunião", contudo, de forma bastante restrita. Seu artigo $1^{\circ}$ trata de reunião "convocada para casa particular ou recinto fechado de associação". Já o artigo $3^{\circ}$ prevê que a autoridade policial local de maior categoria, "ao começo de cada ano, fixará as praças destinadas a comício e dará publicidade a êsse ato" e o seu $\S 2^{\circ}$ exige aviso prévio com antecedência de, pelo menos, 24 horas, para evitar que se realize "outro comício" no mesmo local (BRASIL, 1950).

Única a versar sobre o direito de reunião no âmbito federal, a Lei $n^{0} 1.207 / 1950$ não foi expressamente revogada. Todavia, há razoável consenso doutrinário de que a maior parte do seu conteúdo 
não foi recepcionado pela Constituição de 1988 (FIALHO; RIBEIRO, 2017, p. 78-79), embora, eventualmente, seja aplicada. Nesse sentido:

Lembre-se que, quanto ao aspecto espacial do exercício da liberdade de reunião, a Lei $\mathrm{n}^{0}$ 1.207/1950, aprovada em pleno regime getulista, afirmava em seu artigo $3^{\circ}$ caber à autoridade policial de maior categoria (sic) da localidade, ao começo de cada ano, fixar as praças destinadas a comício. Tal limitação, de duvidosa constitucionalidade, tem sido aplicada em períodos eleitorais com base na remissão do artigo 254, $\S 1^{\circ}$, do Código Eleitoral brasileiro, mas também em períodos não eleitorais, em razão de portarias de delegacias de políticas regionais. No Estado de São Paulo, há inúmeros exemplos dessa natureza. O diário oficial de 14 de março de 2014 apresenta diversos casos: nele, são encontradas portarias de Delegacias delimitando os locais em que a manifestação pública está autorizada nos Municípios de Presidente Prudente, Caraguatatuba, Ilha Bela, Ubatuba, entre outros. Isso mostra o descompasso entre a teoria, que em geral reconhece que tal possibilidade de limitação do exercício do direito de reunião não foi recepcionada pela ordem constitucional instituída em 1988, e a prática institucional, que, sem maior reflexão e controle, aplica conceitos e instrumentos de alta carga autoritária. (DIAS; DE LAURENTIIS, 2014, p. 651-652)

Pode-se alegar que alguns dispositivos do Código de Trânsito Brasileiro (CTB) impõem limites ao direito de reunião, como parece entender Gonçalves (2015), em trabalho sobre a relação e os conflitos entre aquela liberdade e a de circulação (ir e vir). Essa, porém, é uma interpretação duvidosa e de aplicação não sedimentada, apesar de usos eventuais pelo Judiciário 3 e de invocações por parte de opositores aos movimentos.

De forma clara e específica, porém, como dito, não há diploma federal que regulamente o direito constitucional de reunião. Nas esferas locais, a situação é diferente, tendo algumas leis ou atos normativos sofrido questionamentos acerca de sua

\footnotetext{
3 Em 2016, por exemplo, a União obteve liminar, confirmada em sentença em 2017, na $2^{\text {a }}$ Vara Federal da Seção Judiciária da Paraíba, para impedir que movimento de trabalhadores rurais realizasse protesto e ocupação na rodovia BR-101. A juíza Wanessa Figueiredo Lima aplicou o art. $5^{\circ}$, XV, da Constituição, atinente à liberdade de ir e vir, mas também o art. 254, do CTB, destacando não haver incompatibilidade entre este e o direito de reunião. Consignou que "as rodovias não podem ser compreendidas no conceito de 'local aberto ao público", âmbito de alcance do art. $5^{\circ}$, XVI, de modo que sua utilização para as manifestações dependeria de licença das autoridades (BRASIL, 2016).
} 
constitucionalidade. O próprio STF, no julgamento da Ação Direta de Inconstitucionalidade (ADI) 1969/DF, em agosto de 2007, considerou inconstitucional decreto do Distrito Federal que proibira “a realização de manifestação pública, com uso de carros aparelhados e objetos sonoros na Praça dos Três Poderes, Esplanada dos Ministérios, Praça do Buriti e Vias Adjacentes”. O voto do relator, Ministro Ricardo Lewandowski, foi acompanhado por unanimidade (BRASIL, 2007).

Atualmente, pende de análise pela corte o Recurso Extraordinário com Agravo (ARE) no 905.149/RJ (Tema 912), que teve sua repercussão geral reconhecida há quatro anos (BRASIL, 2016). O caso versa sobre a Lei Estadual $n^{0} 6.583 / 2013$, do Rio de Janeiro, que proibiu o uso de máscaras e qualquer outra forma de ocultação do rosto em manifestações públicas. Depois de o diploma ser considerado constitucional pelo tribunal estadual, o diretório regional do Partido da República (PR) interpôs o apelo ao STF. Em março de 2020, o Procurador-Geral da República, Augusto Aras, opinou pelo provimento do recurso, com a consequente declaração de inconstitucionalidade da lei.

Chama a atenção, no aludido parecer, a menção à atual situação de pandemia, na qual "a proteção do direito à saúde, albergado no art. $6^{0}$ da Carta da República, justifica a utilização do equipamento de proteção [máscara] e sua proibição pode significar vedação indireta do direito de reunião". Ao final, propõe a fixação das seguintes teses:

\footnotetext{
I - É inconstitucional a promoção de restrições genéricas ao direito fundamental de reunião.

II - É compatível com o núcleo essencial do direito de reunião a proibição de máscaras e peças que cubram o rosto durante atos de protesto no contexto manifesto da prática de atos de violência e condutas ilícitas, excetuandose da vedação máscaras de proteção contra doenças infectocontagiosas. (BRASIL, 202ob, p. 11)
}

A ausência de lei federal sobre o assunto, no entanto, não significa que inexistam iniciativas legislativas. Pelo contrário. De 2010 a 2015, época de frequentes manifestações no país, que tiveram seu auge nas Jornadas de Junho de 2013, ao menos, 18 projetos foram 
apresentados na Câmara e no Senado, com o intuito de regulamentar o direito de reunião. A maioria visava à proibição de máscaras e outras formas de ocultação do rosto de manifestantes. Outras estabeleciam multas de trânsito ampliadas para organizadores de atos que interrompessem ou bloqueassem o trânsito, vedavam o transporte, porte ou uso de fogos de artifício e especificavam tempo e modo do aviso prévio mencionado pelo art. $5^{\circ}$, XVI, da Constituição (ARAÚJO, 2017, p. 46-49).

Em 2020, novamente, há um momento de acirramento da disputa político-ideológica, desta vez, particularizada pela coexistência com uma pandemia que se dissemina de forma exponencial no país, o que reflete nas medidas e respostas adotadas pelo Executivo e pelo Judiciário em relação à liberdade de reunião.

\section{AS PRIMEIRAS RESPOSTAS: EXECUTIVO E JUDICIÁRIO}

Em episódio raro na história recente da política brasileira, a pandemia de covid-19 estabeleceu uma oposição relevante entre o Executivo federal e o da maioria dos Estados e municípios. Enquanto o presidente Jair Bolsonaro adotou um discurso de minimização dos efeitos da doença, muitos governadores e prefeitos alinharam-se às orientações da Organização Mundial de Saúde (OMS) e de outras entidades nacionais e internacionais, que destacavam a necessidade de distanciamento e/ou isolamento social.

Esses gestores, como consequência, tornaram-se alvos de protestos dos simpatizantes da gestão federal, nas redes sociais, mas também nas ruas. Impuseram, por outro lado, limitações à liberdade dessas reuniões, valendo-se, justamente, das normas de restrição ou proibição de aglomerações editadas em função da pandemia. Os efeitos, porém, não se restringiram aos apoiadores do presidente Jair Bolsonaro.

Em Pernambuco, o Decreto $n^{0} 48.809 / 2020$, que impedia a realização de eventos com mais de 500 pessoas no Estado em razão da 
covid-19, foi invocado como motivo para a detenção de organizador de uma manifestação de rua em apoio ao presidente (VALADARES, 2020). Alguns atos posteriores do mesmo grupo foram realizados na Rodovia BR-232, em frente a unidades do Exército, com o intuito de evitar a jurisdição da Polícia Militar do Estado (VILAR, 2020).

Situação semelhante ocorreu no Pará, com 112 pessoas detidas em protesto contrário ao governo federal e ao racismo (BATISTA JR., 2020). Neste caso, porém, há particularidade relevante. O Decreto Estadual $n^{0} 609 / 2020$ suspendeu, expressamente, durante sua vigência, “a realização de eventos, reuniões, manifestações, carreatas e/ou passeatas, de caráter público ou privado e de qualquer espécie, com audiência maior ou igual a 10 (dez) pessoas" (PARÁ, 2020). Portanto, o Executivo local criou restrições significativas - ainda que temporárias - ao exercício do direito constitucional de reunião.

No Distrito Federal, o Decreto $\mathrm{n}^{0}$ 40.884/2020 proibiu o trânsito de veículos e pedestres na área da Esplanada dos Ministérios, ao longo dos dias 16 e 17 de junho. Os "considerandos" do ato evidenciam que teve, como motivação, a previsão de realização de manifestações no local, ao mencionar "as aglomerações verificadas nos últimos dias [...] que contrariam as medidas sanitárias de combate ao novo coronavírus"; "as ameaças declaradas por alguns dos manifestantes aos Poderes constituídos" e a "a ameaça de manifestações com conteúdos anticonstitucionais" (DISTRITO FEDERAL, 2020).

A edição desses decretos é criticada por Gusmão e Guimarães (2020, p. 115). Embora defendam a regulamentação do direito de reunião, como mecanismo para assegurar maior garantia àquela própria liberdade, os autores ressaltam ser "evidente que os conceitos de aglomeração e de reunião, para efeitos jurídicos, são diferentes, afinal, a liberdade de reunião é instrumental que serve ao exercício de direitos em sua dimensão coletiva, enquanto a aglomeração não seria dotada dessa finalidade”. 
Sob o aspecto formal, observam que eventuais restrições somente poderiam ser "veiculadas por meio de categorias normativas com nível de lei" (GUSMÃO; GUIMARÃES, 2020, p. 115). O ponto é compartilhado por Nelson, Fernandes e Nelson (2020), que lembram a cláusula de reserva legal inscrita no art. 15 da Convenção Americana sobre Direitos Humanos (Pacto de São José da Costa Rica), ratificado pelo Brasil em 1992. O dispositivo autoriza que o direito de reunião esteja "sujeito às restrições previstas pela lei e que sejam necessárias" para assegurar outros bens jurídicos, inclusive "para proteger a saúde" (OEA, 1969).

Não foi só por meio de decretos, porém, que estados e municípios buscaram restringir o direito de reunião. O governador de São Paulo, João Dória, em março, havia descartado a possibilidade de vetar manifestações de rua em função da pandemia (BERGAMO, 2020). Após os protestos de 31 de maio, que opuseram simpatizantes e opositores do governo federal, contudo, o Executivo estadual propôs ação judicial, tendo obtido liminar para proibir que grupos antagônicos realizassem os atos previstos para o dia o7 de junho e finais de semana subsequentes, na Avenida Paulista (CORREIO BRAZILIENSE, 2020; BOEHM, 2020).

O exemplo paulistano ilustra a atuação, também, do Judiciário na restrição do exercício do direito de reunião, em tempos pandêmicos. Manifestações foram proibidas por decisões judiciais em Campinas (UOL, 2020), Curitiba (PARANÁPORTAL, 2020), Rio de Janeiro (GAZETA DO POVO, 2020), Goiás, Maranhão e, ainda, nos municípios paulistas de Ribeirão Preto e Piracicaba (ESTADO DE MINAS, 2020). As ações foram propostas, em sua maioria, por prefeituras ou pelo Ministério Público estadual, sendo as liminares proferidas com fundamento no risco de aglomeração e propagação da covid-19.

Tanto as iniciativas do Poder Executivo estadual e municipal, quanto tais decisões judiciais configuraram, no entender de Cavalcanti, Neto e Cerqueira (2020, p. 480), uma "mutação inconstitucional por violar o espírito da Carta Magna". Isso porque o 
texto da Constituição de 1988 estabelece hipóteses específicas e bem delineadas que autorizariam a restrição a determinadas liberdades, quais sejam, o Estado de Sítio e o Estado de Defesa, nenhum deles adotado durante a pandemia.

Não é possível, pois, a partir de previsões genéricas da Constituição, como o direito à saúde, extrair-se uma autorização para a adoção de medidas que atentem contra o regramento constitucional específico da matéria de restrições excepcionais aos direitos individuais do cidadão. $\mathrm{O}$ esmero do constituinte nesse ponto simplesmente não faria sentido caso se pudessem criar novas hipóteses de restrição desses direitos pelo arbítrio de quaisquer autoridades, desde o Prefeito até o Presidente da República, ainda que com justificativa em motivos nobres como o combate ao Covid-19 (CAVALCANTI; NETO; CERQUEIRA, 2020, p. 480-481).

O pano de fundo constitucional ajuda a compreender por que, apesar dos diversos pronunciamentos de juízes e tribunais locais, as atenções em relação ao exercício do direito de reunião na pandemia recaem sobre a atuação do STF. Por um lado, a Corte abriu inquérito sobre atos considerados antidemocráticos, a pedido da Procuradoria Geral da República. Embora também alcance condutas em plataformas virtuais, a investigação contempla manifestações promovidas por simpatizantes do governo federal (por vezes, apoiadas publicamente pelo presidente Jair Bolsonaro ou ministros), já tendo resultado em decretação de prisões preventivas e ordens de quebra de sigilos e de busca e apreensão (G1, 2020c).

Por outro lado, em decisão monocrática, o decano do STF, Ministro Celso de Mello, não conheceu de pedido de medida cautela (PET $8830 \mathrm{MC} / \mathrm{DF}$ ) proposto por deputado do Partido dos Trabalhadores (PT) com o objetivo de proibir carreata organizada para protestar contra a própria Corte. O relator entendeu que o tribunal não exerceria a competência penal originária para apreciar a notícia-crime, o que justificaria a sua inadmissão. Porém, ele foi além e, em aparente 
obiter dictum 4 , teceu considerações também sobre aspectos materiais do direito de reunião.

O Ministro destacou que a pretensão de impedir uma carreata ou manifestação "transgride frontalmente a liberdade de reunião" e que seu acolhimento importaria o desrespeito à liberdade de expressão. Recordando os julgamentos da ADI 1.969/DF e do HC 4.781/BA, concluiu que, nos dois casos, o STF "deixou claramente consignado que o direito de reunião, enquanto direito-meio, atua em sua condição de instrumento viabilizador do exercício da liberdade de expressão". Mais adiante, consignou que, sem prejuízo de eventuais excessos serem alcançados pelo direito penal, seria "frontalmente inconstitucional qualquer medida que implique a inaceitável 'proibição estatal do dissenso' ou a livre manifestação do pensamento" (BRASIL, 2020a).

Embora não exista julgado colegiado do STF acerca das manifestações hodiernas, convém observar que a decisão proferida pelo Ministro Celso de Mello guarda semelhanças com os acórdãos da Arguição de Descumprimento de Preceito Fundamental (ADPF) $\mathrm{n}^{\mathrm{o}}$ 187/DF e da Ação Direta de Inconstitucionalidade (ADI) no 4.274/DF, ambas sobre a chamada Marcha da Maconha, que visa à descriminalização ou legalização da(s) droga(s).

No primeiro caso, o próprio Ministro Celso de Mello, enquanto relator, destacou que "o Estado, por seus agentes e autoridades, não pode cercear nem limitar o exercício do direito de reunião, apoiandose, para tanto, em fundamentos que revelem oposição governamental ao conteúdo político, doutrinário ou ideológico do movimento" 5 ,

4 Conceito caraterístico da cultura do stare decisis, predominante nos países da Common Law, como Reino Unido e Estados Unidos. Embora haja controvérsia doutrinária, serve ao trabalho a definição de Taruffo (2011, p. 145-146), para quem o obiter dictum compreende "todas aquelas afirmações e argumentações que estão contidas na motivação da sentença, mas que, mesmo podendo ser úteis para a compreensão da decisão e dos seus motivos, todavia não constituem parte integrante do fundamento jurídico da decisão". Na decisão analisada, o fundamento central (ratio decidendi) para o não conhecimento do pedido é de ordem formal, atinente à incompetência do STF, de modo que as considerações sobre a substância do direito reunião constituem mero obter dictum.

$5 \mathrm{O}$ voto interpreta de forma extensiva o requisito da pacificidade da reunião, devendo a manifestação, para merecer a proteção constitucional, ser realizada "'sem 
tampouco é possível restringir a manifestação a partir do "mero juízo de oportunidade, de conveniência ou de utilidade” (BRASIL, 2011a, p. 21).

$\mathrm{Na} A D I n^{\circ} 4.274 / D F$, o voto do relator, Ministro Ayres Britto, acompanhado por unanimidade, consignou que o direito de reunião não poderia ser restringido ou suprimido em função da pauta da manifestação (BRASIL, 2011b).

A recente decisão do Ministro Celso de Mello aproxima-se, ainda, de dois acórdãos do Tribunal Constitucional Federal (Bundesverfassungsgericht) da Alemanha em abril. Nos processos BVerfG 1 BvR 828/20 e BVerfG 1 BvQ 37/20, esta Corte acolheu queixas ajuizadas contra proibições de protestos nas cidades de Gießen e Stuttgart, respectivamente (FRITZ, 2020).

No primeiro caso, a manifestação ocorreria em quatro dias seguidos, com o compromisso de observância de medidas de segurança contra a covid-19. O objetivo era protestar contra medidas governamentais que, sob a justificativa de combate à pandemia, estariam atingindo indevidamente direitos fundamentais dos cidadãos.

Após a proibição do ato, o Tribunal Constitucional deferiu medida liminar requerida pelos manifestantes, fundada no artigo 8.1 da Lei Fundamental (Constituição alemã), que também garante o direito de reunião pacífica e sem armas, independentemente de registro ou permissão. A Corte consignou que, embora o artigo 8.2 permita a restrição por lei ou com base em lei, essa não seria a hipótese dos autos, na medida em que a decisão do governo do Estado de Hesse não continha vedação geral de reunião ao ar livre. O Tribunal considerou que a vagueza e a imprecisão do ato normativo não atendiam aos parâmetros constitucionais relacionados à liberdade de reunião, nem consideravam as peculiaridades do caso concreto, 
impedindo a avaliação adequada dos impactos sobre o direito fundamental, o qual, nesse cenário, deveria ser protegido (FRITZ, 2020; ALEMANHA, 2020a).

A decisão, no entender de Corao (2020, p. 4-5), é um dos "exemplos de interpretação constitucional razoável e limitada de restrições impostas por autoridades durante a pandemia, evidenciando a importância do funcionamento dos tribunais durante a emergência sanitária" 6 . Isso porque a Corte alemã não concedeu uma autorização generalizada para manifestações públicas, tendo somente instado as autoridades e tribunais inferiores a proceder uma análise motivada, caso a caso.

No caso do BVerfG 1 BvQ 37/20, a manifestação contrária ao regime de emergência instituído durante a pandemia ocorreria em duas datas. A administração proibiu sua realização, em razão do risco de infecção pela covid-19. Embora tenha reconhecido a plausibilidade do motivo invocado, o Tribunal Constitucional considerou que o Executivo local deveria ter buscado soluções acordadas com os organizadores do protesto, analisando as particularidades do caso, em vez de proibir a manifestação de forma abstrata, e, assim, violar o direito de reunião, inclusive com efeitos sobre futuros atos (FRITZ, 2020; ALEMANHA, 2020b).

\section{DIREITO DE REUNIÃO E LEGISLATIVO EM TEMPOS DE PANDEMIA}

Não é surpreendente que as primeiras medidas ou pronunciamentos acerca do direito de reunião nos tempos atuais tenham sido fornecidas por Executivo e Judiciário. Não se trata de crítica específica ao Legislativo brasileiro, mas de uma percepção

\footnotetext{
6 Tradução dos autores. No original, em espanhol: "Sin embargo, existen buenas prácticas que pueden ser citadas como ejemplos de interpretación constitucional razonable y limitada, de las restricciones impuestas por las autoridades durante la pandemia y, que evindecian la importancia del funcionamento de los tribunales durante esta emergencia sanitaria."
} 
histórica, de que as mudanças na legislação costumam exigir mais tempo - o que, aliás, é argumento para a defesa da função criativa judicial, como forma de adequação do direito à realidade social (SOUZA, 1996).

Contudo, o cenário delineado a partir de março de 2020 repercutiu rapidamente também no Congresso Nacional, como será demonstrado com a pesquisa descrita a seguir, que revela uma espécie de repetição do que ocorrera entre 2010 e 2015, época de diversas manifestações nas ruas do país e, simultaneamente, de intensa produção legislativa ligada ao exercício (e, especialmente, aos limites) do direito de reunião.

\subsection{Descrição e resultados do levantamento dos dados}

Nas páginas oficiais da Câmara dos Deputados (https://www.camara.leg.br/) e do Senado (https://www12.senado.leg.br/), é possível consultar as propostas legislativas a partir de diversas variáveis e informações. Para este artigo, adotou-se a busca pelas palavras-chaves "manifestações", "manifestação", "protestos", "protesto", “direito de reunião", "liberdade de reunião", "art. $5^{\circ}$, XVI", "art. $5^{\circ}$, inc. XVI" e "art. $5^{\circ}$, inciso XVI".

Dos resultados exibidos, foram considerados apenas projetos apresentados no ano de 2020, tendo o dia 20 de junho como termo final. A partir daí, foi verificado se a proposta tem pertinência ou não com o direito de reunião e, ainda, se seus motivos estão, direta ou indiretamente, relacionados ao momento político e/ou à pandemia de covid-19.

No site da Câmara, foram selecionados os tipos de proposição PEC (Proposta de Emenda à Constituição), PLP (Projeto de Lei Complementar), PL (Projeto de Lei), MPV (Medida Provisória), PLV (Projeto de Lei de Conversão), PDL (Projeto de Decreto Legislativo), 
PDN (Projeto de Decreto Legislativo - CN), PDS (Projeto de Decreto Legislativo - SF), PLC (Projeto de Lei da Câmara dos Deputados - SF), PLN (Projeto de Lei - CN) e PLS (Projeto de Lei do Senado Federal).

Da pesquisa, resultaram 56 proposições para a palavra-chave "manifestações", 95 para "manifestação", 14 para "protestos", 23 para "protesto", 2 para "direito de reunião", 2 para "liberdade de reunião", 3 para "art. $5^{\circ}$, XVI". Nada foi localizado para as expressões "art. $5^{\circ}$, inc. XVI" e "art. $5^{\circ}$, inciso XVI". Algumas propostas foram identificadas mais de uma vez, amoldando-se a mais de um termo de busca.

Na Câmara, foram identificados 10 (dez) projetos de lei cuja eventual aprovação afetaria o exercício do direito de reunião, a maioria deles contendo justificativas atreladas aos recentes fatos políticos e/ou à pandemia de covid-19. Além deles, há propostas cujos efeitos são reduzidos ou colaterais, como a restrição de uso da bandeira nacional, as quais não foram consideradas no levantamento.

\section{PL 1932/2020. Autor: Alexandre Frota (PSDB) - Data de apresentação: 15.04.2020}

Resumo quanto ao direito de reunião: Proíbe manifestações públicas que gerem aglomerações de pessoas enquanto durarem os efeitos jurídicos do estado de calamidade pública (Decreto Legislativo $\left.n^{0} 6 / 2020\right)$.

Justificativa (momento político ou covid): Menciona o "atual estado de pandemia causado pelo coronavírus" e o intuito de proteger a população dos seus efeitos (BRASIL, 2020c).

\section{PL 2387/2020. Autor: André Figueiredo (PDT) - Data de apresentação: 04.05.2020}

Resumo quanto ao direito de reunião: Tipifica, como crime contra o Estado e a Ordem Política e Social (Lei $n^{0}$ 1802/1953) a prática de "ato público que exprima menosprezo, vilipêndio ou ultraje a qualquer instituição que integre os Poderes da República”. 
Justificativa (momento político ou covid): Faz alusão a “manifestações populares preocupantes” ocorridas em "período de isolamento social”, com o intuito de "atentar" contra o Estado Democrático de Direito. Cita, especificamente, manifestação de 03.05.2020, com participação do presidente Jair Bolsonaro e ofensas ao STF (BRASIL, 2020d).

\section{PL 2464/2020. Autor: André Figueiredo (PDT) - Data de apresentação: 07.05.2020}

Resumo quanto ao direito de reunião: Altera a Lei 7.170/1986, para tipificar, como crime contra a segurança nacional, ordem política e social, a promoção ou participação de ato contra o livre exercício dos Poderes, a forma federativa do Estado, a separação dos poderes, os direitos e garantias individuais, a dissolução do Congresso, o livre exercício do Judiciário e a atuação das Forças Armadas fora de suas atribuições, entre outros.

Justificativa (momento político ou covid): Menciona "a escalada do discurso autoritário que aflige as democracias contemporâneas e, notadamente, a brasileira”, porém, sem especificar fato ou personalidade (BRASIL, 2020e).

\section{PL 2917/2020. Autor: Guilherme Derrite (PP) - Data de apresentação: 26.05.2020}

Resumo quanto ao direito de reunião: Altera a Lei $n^{0}$ 1079/1950, para tipificar, como crime de responsabilidade de prefeito ou governador, a violação de direitos fundamentais ou a adoção, durante estado de calamidade pública, de medidas de repressão que excedam os limites estabelecidos na Constituição.

Justificativa (momento político ou covid): Alude, sem citar casos específicos, a flexibilizações de direitos fundamentais "sem qualquer parâmetro técnico e razoável" no âmbito estadual, em nome de medidas sanitárias. Destaca, na justificativa, que a liberdade de reunião só pode ser suspensa em estado de sítio (BRASIL, 2020f). 
PL 2996/2020. Autor: Osires Damasco (PSC), Bia Kicis (PSL), Carla Zambelli (PSL), Hélio Lopes (PSL) e outros (PSC, PSL e PL) - Data de apresentação: 29.05.2020

Resumo quanto ao direito de reunião: Altera a Lei 13.869/2019, a Lei 1.079/1950 e o Decreto-Lei 201/1967, para tipificar, como abuso de autoridade e como crime de responsabilidade, entre outros atos, o de impedir "sob qualquer pretexto e de forma indeterminada e generalizada, o legítimo exercício de direitos constitucionais” previstos no art. $5^{\circ}$, da $\mathrm{CF}$, incluindo o de reunião (inc. XVI), “em tempos de paz, ainda que sob a vigência de estado de calamidade pública”.

Justificativa (momento político ou covid): Alega que não é cabível a restrição a liberdades constitucionais mesmo no cenário atual, de pandemia de covid-19, afirmando que "não há consenso na Ciência com relação à real eficiência de medidas restritivas de liberdade para a preservação da saúde da população”. Não faz menção a atos ou medidas específicas (BRASIL, 2020g).

PL 3019/2020. Autor: Daniel Silveira (PSL) - Data de apresentação: 01.06.2020

Resumo quanto ao direito de reunião: Altera a Lei 13.260/2016 para considerar “organização terrorista os grupos denominados antifas (antifascistas) e demais organizações com ideologias similares”.

Justificativa (momento político ou covid): Refere-se aos atos realizados em São Paulo, no dia 31.05.2020 (manifestações contra o presidente Jair Bolsonaro), e a uma sequência de "sem número de ameaças de prática de violência, inclusive com o uso de armas ilegais" (BRASIL, 2020h).

PL 3083/2020. Autor: Carlos Jordy (PSL) - Data de apresentação: 02.06.2020 
Resumo quanto ao direito de reunião: Altera a Lei 13.260/2016 para incluir razões políticas entre as motivações das práticas enquadradas como terrorismo e especifica a aplicação "à conduta individual ou coletiva de pessoas em manifestações políticas, movimentos sociais, sindicais, religiosos, de classe ou de categoria profissional e de torcidas organizadas".

Justificativa (momento político ou covid): Menciona que "recentemente [...] grupos políticos armados, sob alcunha de torcida organizada, agiram em alguns centros do país contra manifestantes com a finalidade de levar terror e afastar idosos, mulheres, crianças e demais das ruas, inibindo e constrangendo o direito constitucional de reunião". Possível alusão implícita às manifestações de 31.05.2020, em São Paulo. Refere-se, também, a 7 “atos pró-Bolsonaro (...) onde só houve distúrbio social e violência quando do aparecimento destes grupos ligados às organizações criminosas de esquerda, como é o PT e o Foro de São Paulo” (BRASIL, 2020i).

\section{PL 3116/2020. Autor: Luiz Philippe de Orleans e Bragança (PSL) - Data de apresentação: 03.06.2020}

Resumo quanto ao direito de reunião: Altera a Lei 13.260/2016, para tipificar, como crime de terrorismo, práticas como incendiar, depredar, saquear bem público ou privado, entre outros equipamentos, "em contexto de abuso do direito de promover protesto”.

Justificativa (momento político ou covid): Não faz qualquer menção expressa ao contexto político ou à pandemia de covid-19 (BRASIL, 2020j).

PL 3226/2020. Autor: Nereu Crispim (PSL) - Data de apresentação: 09.06.2020

Resumo quanto ao direito de reunião: Acrescenta à Lei 7.170/1983 os crimes de promover, constituir, financiar, integrar ou participar de ato público contra a forma federativa do Estado, a 
separação dos Poderes, os direitos e garantias individuais, o regular funcionamento do Congresso e das Forças Armadas. Tipifica, como terrorista (Lei 13.260/2016), a prática de atos por razões de ideologia política, incluindo manifestação pública atentatória à democracia, à separação dos Poderes, ao regular funcionamento do Congresso, entre outros.

Justificativa (momento político ou covid): Apresenta resumo histórico sobre o Ato Institucional $\mathrm{n}^{0} 5$, de 1968, e menciona que "alguns membros do governo recorreram ao artigo 142 da Constituição Federal” para tentar justificar a possibilidade de intervenção militar, o que é contrariado por especialistas e pelo Procurador-Geral da República, Augusto Aras, em trechos transcritos na justificativa (BRASIL, 2020k).

\section{PL 3319/2020. Autor: Vitor Hugo (PSL) - Data de apresentação: 15.06.2020}

Resumo quanto ao direito de reunião: Altera a Lei 13.260/2016 para incluir as motivações de ordem política entre aquelas que caracterizam os atos de terrorismo.

Justificativa (momento político ou covid): Menciona "ameaças terroristas" quando da posse do presidente Jair Bolsonaro e manifestações recentes realizadas por "Antifas e grupos similares que pedem a luta armada para a tomada do poder" (BRASIL, 2020l).

No site do Senado, foram buscados todos os tipos de proposições legislativas, já que a página permite a seleção de apenas uma espécie ou de todas, sem possibilidade de escolha de algumas opções concomitantes. Adotaram-se o mesmo intervalo temporal (01.01.2020 a 20.060.2020) e as mesmas palavras-chaves no campo de pesquisa textual.

A única palavra-chave que retornou algum resultado foi "manifestação". Contudo, a resposta do site remetia a requerimento de informações ao Ministro de Estado da Justiça e Segurança Pública, 
portanto, não se tratava de proposta legislativa atrelada ao direito de reunião.

\subsection{Conclusões do levantamento dos dados}

Uma conclusão óbvia do levantamento é a de que a questão relativa ao direito de reunião, no cenário atual, apenas mobilizou os deputados federais, já que nenhuma proposta sobre o tema foi apresentada no Senado. Por outro lado, verifica-se que o número de projetos na Câmara é significativo e apresentou tendência expressiva de aumento a partir da última semana de maio. Entre 26 de maio e 20 de junho, último dia considerado na pesquisa, foram apresentadas 7 (sete) das 10 (dez) proposições identificadas.

Esse período coincide com o surgimento de manifestações de rua contrárias ao governo do presidente Jair Bolsonaro. O primeiro protesto com um número relevante de participantes e cobertura midiática ocorreu em 31 de maio de 2020. Até então, o que se verificava era apenas a repetição, com periodicidade semanal (geralmente, aos domingos), de atos de apoio ao governo federal.

Há uma correlação importante entre a tendência políticoideológica dos atos e a origem e o conteúdo das propostas legislativas. Os três projetos apresentados antes de 26 de maio continham, nas suas justificativas, críticas indiretas ao governo federal ou a seus apoiadores, conferindo destaque negativo à realização de manifestações públicas em período de pandemia e baseadas em discursos autoritários e contrários ao Estado Democrático de Direito. Depois daquela data, apenas uma proposição (a de $n^{0} 3226 / 2020$ ) reflete posicionamento semelhante.

Por outro lado, deputados alinhados ao governo federal - que vinha exortando o caráter democrático das manifestações a seu favor e o direito dos cidadãos de participar de tais atos, mesmo durante a pandemia - não haviam apresentado qualquer proposta relativa à 
liberdade de reunião até 26 de maio. Contudo, foram responsáveis por 6 (seis) dos 7 (sete) projetos de lei submetidos desde então, sendo que 3 (três) deles contêm, em suas justificativas, alusões explícitas aos protestos realizados contra o governo federal.

Os achados do levantamento empreendido sugerem um aspecto problemático do sistema jurídico-político brasileiro, pretensamente democrático, qual seja, a mobilização dos legisladores visando à regulamentação ou à restrição do direito fundamental como forma de conter a oposição. Trata-se de um comportamento que guarda semelhanças com episódio ocorrido no Quirguistão e destacado pela Oxfam. Segundo o documento, um tribunal de Bhiskek invocou a pandemia, quando ainda não havia casos de coronavírus no país, para impor uma proibição a reuniões por um período de quatro meses, justamente após a realização de protestos da oposição política e dias antes de uma marcha pelo Dia Internacional da Mulher. Este último evento foi realizado e as participantes foram presas, enquanto foi permitido aos homens que se reunissem para uma cerimônia tradicional de sacrifício de cabras, para afastar a covid-19 (SAUNDERS, 2020).

Outra conclusão relevante da pesquisa é a de que os deputados federais tendem a buscar no direito penal (em tese, a ultima ratio) as respostas para o que consideram excessos ou abusos do direito de reunião. Metade dos projetos identificados pretende tipificar alguns atos como crimes de terrorismo, alterando a Lei ${ }^{0} 13.260 / 2016$, cujo $\S 2^{\circ}$, do art. $2^{\circ}$, atualmente, descarta sua aplicação às condutas realizadas no exercício daquela liberdade.

Quatro dos projetos que buscam alterar aquela lei contêm justificativas favoráveis ao governo federal. O único de tendência contrária é de autoria de um deputado do Partido Social Liberal (PSL), portanto, correligionário da maioria dos signatários das propostas alinhadas à gestão do presidente Jair Bolsonaro, ele próprio um exafiliado, hoje sem partido.

Uma última conclusão, extraída da justificativa dos projetos identificados, diz respeito à relação entre a atual produção legislativa 
sobre direito de reunião e a pandemia. Se os riscos de disseminação do coronavírus foram invocados por Executivos locais e por parte do Judiciário para impor limitações a manifestações públicas nos últimos meses, tal argumento não ocupou papel de destaque no Congresso.

Apenas três das dez propostas apresentadas na Câmara fazem alusão significativa à pandemia em suas justificativas, e somente uma delas (no 1932/2020) expõe a preocupação com a disseminação da doença mediante a realização de manifestações públicas. As outras duas voltam-se contra as medidas, adotadas sobretudo por autoridades locais, relativas à restrição excepcional ao exercício do direito de reunião, questionando, inclusive, as bases científicas de tais decisões. Ambas se destinam à responsabilização dos agentes políticos, com a tipificação de suas condutas como abuso de autoridade e/ou crime de responsabilidade.

\section{A EFICÁCIA do ART. 5\%, XVI, DA CONSTITUIÇÃo FEDERAL E A TEORIA DOS LIMITES DOS LIMITES}

O êxito dos projetos de lei identificados dependerá, evidentemente, do contexto político do país, a cujo respeito não convém traçar previsões, dada a contínua combustão ocasionada por múltiplos fatores, desde a ameaça de intervenção ou golpe militar até as suspeitas e acusações criminais contra o presidente e seus familiares, passando pela evolução das manifestações nas redes sociais e, claro, nas ruas. Contudo, ainda que algum deles venha a ser aprovado no Congresso e sancionado pela Presidência da República, devem surgir dúvidas quanto a sua constitucionalidade.

Isso porque não existe uma posição unânime quanto à eficácia do inciso XVI, do art. $5^{\circ}$, da Constituição, e à possibilidade de limitação no plano infraconstitucional. Em relação ao primeiro ponto, 
convém lembrar a disseminada - porém, não unânime7 - classificação proposta por Silva (1993, p. 10), segundo a qual as normas constitucionais podem ser: a) "de eficácia plena e aplicabilidade direta, imediata e integral"; b) "de eficácia contida (ou contível) e aplicabilidade direta, imediata, mas possivelmente não integral"; e c) "de eficácia limitada", as quais se subdividem em "declaratórias de princípios institutivos ou organizativos" e "declaratórias de princípios programáticos".

O primeiro grupo compreende as normas que "produzem ou têm a possibilidade de produzir todos os efeitos essenciais" de forma direta e imediata, "porque dotadas de todos os meios e elementos necessários à sua executoriedade, não requerendo normatividade alguma ulterior para sua aplicação”. As de eficácia contida ou contível "têm natureza de normas imperativas, positivas ou negativas, limitadoras do Poder Público, valendo dizer, consagradoras, em regra, de direitos subjetivos dos indivíduos ou de entidades públicas ou privadas". Subsiste, assim, uma "margem à atuação restritiva da competência discricionária do Poder Público, nos termos que a lei estabelecer ou nos termos de conceitos gerais nela enunciados", a fim de conferir limites à norma. Esta, contudo, tem aplicabilidade imediata e direta, isto é, independente da interferência do legislador ordinário (SILVA, 1993, p. 10-11).

A eficácia e a aplicabilidade das normas de eficácia limitada, por fim, dependem de lei ou processo especial ulterior. Podem limitar-se a traçar "esquemas gerais de estruturação e atribuições de órgãos, entidades ou instituições" (princípio instituto ou organizativo) ou a estabelecer princípios a serem cumpridos pelos órgãos estatais, sem qualquer regulação direta e imediata pelo texto da Constituição. As primeiras, ressalta Silva (1993, p. 11), podem ser identificadas por

\footnotetext{
7 Virgílio Afonso da Silva reconhece que a classificação proposta por José Afonso da Silva em 1966, durante a ditadura militar, teve o mérito de romper com a concepção de norma constitucional despida de eficácia. Porém, no seu entender, todas as normas constitucionais de proteção aos direitos fundamentais sempre têm alguma limitação na sua eficácia. Assim, a regulamentação/restrição seria importante para permitir ou estimular ações que criem condições de concretização daqueles direitos, servindo como mecanismo de efetiva proteção (SILVA, 2006).
} 
meio de expressões como "a lei complementar estabelecerá...”, “a lei disciplinará...”, “nos termos da lei...”, entre outras.

$\mathrm{O}$ autor, contudo, ressalva que o art. $5^{\circ}, \S 1^{\circ}$, da Constituição ("as normas definidoras dos direitos e garantias fundamentais têm aplicação imediata”) não significa que os direitos fundamentais sejam, necessariamente, de eficácia plena. Na realidade, em regra, as normas que "consubstanciam os direitos fundamentais democráticos e individuais são de eficácia contida e aplicabilidade imediata” (SILVA, 1993, p. 21).

No caso específico do direito de reunião, o texto constitucional suscita polêmicas. Morais e Silva (2016, p. 44) entendem que a norma goza de eficácia plena, de modo que "não pode o legislador infraconstitucional limitar os seus efeitos”. Aparentemente, a mesma opinião foi defendida pelo ex-Ministro do STF Ayres Britto, enquanto relator da $\mathrm{ADI}$ 4.274/DF, oportunidade em que consignou que qualquer restrição àquela liberdade somente poderia ser admitida nas situações excepcionais do estado de defesa e de sítio, previstas nos arts. 136 e 139, da Constituição (BRASIL, 2011b).

Quatro anos antes, no julgamento da ADI 1.969-4, Ayres Britto havia deixado seu entendimento ainda mais claro, ao referir-se ao art. $5^{\mathrm{o}}$, XVI, da Constituição:

\footnotetext{
Relativamente à matéria, a Constituição brasileira é tão enfática e comprometida com a liberdade de reunião, que chega a ser regulamentar. Num dispositivo de eficácia plena, quanto ao seu teor de normatividade, ela não só consagra o direito de reunião como também, por conta própria, indica todas as condições para o exercício desse direito (BRASIL, 2007, p. 394)
}

Na deliberação sobre a ADI 1.969-4/DF, o ex-Ministro Eros Grau, embora tenha concordado com o relator, Ministro Ricardo Lewandowski, para dar procedência à demanda, consignou que "o direito de reunião pode até ser regulamentado, mas não por decreto, só por lei” (BRASIL, 2007, p. 383).

Em ambos os julgamentos (ADI 4.274/DF e 1.969-4/DF), o Ministro Gilmar Mendes expressou sua preocupação com o objeto da 
decisão, ressalvando "a hipótese ou necessidade de que o legislador, eventualmente, viesse a estabelecer algum tipo de limitação" ao direito constitucional de reunião. Ele, inclusive, entende que partes do art. $5^{\circ}$, XVI - "desde que não frustrem outra reunião anteriormente convocada para o mesmo local" e "sendo apenas exigido prévio aviso à autoridade competente" - sugerem o problema de eventuais colisões e a demanda por "algum tipo de disciplina" (BRASIL, 2007, p. 399400). Na percepção do ministro, haveria uma reserva legal implícita.

Prevalecendo a ideia de Ayres Britto em eventual novo julgamento sobre o direito de reunião, há significativa probabilidade de que um dos projetos mencionados na seção anterior, caso transformado em lei, seja considerado inconstitucional. Porém, ainda que se assuma que o art. $5^{\circ}$, XVI, da Constituição, está suscetível à regulamentação infraconstitucional, a doutrina entende que há limites para tanto.

Dimoulis e Lunardi (2016, p. 175) opinam que as limitações do direito de reunião "para preservar outros direitos fundamentais, em particular a liberdade econômica e a segurança dos demais" podem ser realizadas pelo Executivo e pelo Judiciário em casos concretos, mas, também, pela possibilidade de edição de "lei harmonizadora". O foco, nesta última hipótese, seria o estabelecimento de competências e procedimentos, como, por exemplo, as regras relativas ao prévio aviso mencionado no art. $5^{\circ}$, XVI, da Constituição.

Por isso, reputam inconstitucionais leis como a de $\mathrm{n}$. 6.528/2013, do Rio de Janeiro, que veda de forma genérica o uso de máscaras ou outras formas de cobrir o rosto, e a de $n^{0} 18.363 / 2014$, de Goiás, que impõe comunicação prévia de 30 dias, a necessidade de concordância da polícia militar, a proibição de reuniões que causem "transtornos ou impedimentos à mobilidade urbana" ou que prejudiquem "a tranquilidade e a salubridade pública" (DIMOULIS; LUNARDI, 2016, p. 171-172).

Martins (2017, p. 482) destaca que o fato de o direito de reunião, como previsto na Constituição, prescindir de regulamentação legislativa, não significa que uma lei com tal desiderato seja, de plano, 
inconstitucional. Ele propõe um exame sistemático, que passa pelo juízo de proporcionalidade, pelos limites de competência dos poderes estatais, mas, também, pela abertura que o próprio texto constitucional propicia a eventuais restrições a direitos fundamentais.

Em síntese, entende o autor que o art. $5^{\circ}$, XVI, contém duas condições subjetivas (caráter pacífico e ausência do porte de armas) e uma delimitação espacial ("em locais abertos ao público"). Já as locuções "exigência" de "prévio aviso a autoridade competente" e "desde que não frustrem outra reunião anteriormente convocada para o mesmo local" representariam limites autorizadores de intervenções pontuais, com definição de pressupostos gerais, pelo legislador ordinário. Do mesmo modo, seria possível a aplicação de leis (como os arts. 329 e 331, do Código Penal) contra abusos no exercício da liberdade de reunião, desde que atendidos requisitos de constitucionalidade $^{8}$, proporcionalidade e compatibilidade (MARTINS, 2017).

A proporcionalidade também está na base da teoria dos limites dos limites, de origem alemã, segundo a qual "as reservas legais que incidem sobre os direitos fundamentais permitem que o legislador intervenha nesses direitos, a fim de que eles sejam restringidos em determinadas situações, sobretudo em face da preservação de outros bens jurídicos relevantes". Porém, tal autorização não tem alcance absoluto. A possibilidade de o legislador limitar aqueles direitos não pode atingir seu núcleo essencial, aquele conteúdo (de difícil definição) que deve permanecer "preservado, mesmo após a incidência dessas restrições" (DUQUE; NASCIMENTO, 2018, p. 958).

Estas breves considerações não pretendem esgotar o debate acerca da eficácia e da aplicabilidade da liberdade de reunião, tampouco a construção doutrinária e jurisprudencial acerca do

\footnotetext{
${ }^{8} \mathrm{O}$ autor afirma que, como o art. $5^{\circ}$, XVI, da Constituição, não contém reserva legal expressa, "vem à pauta apenas um limite derivado do chamado direito constitucional de colisão. Trata-se de intervenções que possam estar baseadas em norma constitucional, hipótese em que o órgão interventor teria de estar, para esse efeito, perseguindo a concretização de um bem jurídico constitucional" (MARTINS, 2017, p. 472).
} 
conteúdo essencial dos direitos fundamentais e das possibilidades de sua limitação. Não obstante, são necessárias diante da profusão de liminares judiciais, decretos executivos e propostas legislativas que restringem, em maior ou menor grau, a realização de manifestações públicas. Provavelmente, tais questões teóricas - com evidentes motivações e implicações práticas - estarão em pauta, sempre que as referidas iniciativas forem postas em discussão em espaços políticos e jurídicos.

Tomando-se, como exemplos, os decretos estaduais e decisões judiciais que proibiram manifestações públicas em virtude da covid19, assim como o projeto de lei ${ }^{0}{ }^{0}$.932/2020, que pretende suspender a liberdade de reunião durante a pandemia, é razoável defender o motivo de fundo (direitos, também de ordem constitucional e fundamental, à vida e à saúde). Contudo, impende verificar se a total vedação atende ao juízo de proporcionalidade, preserva o núcleo essencial do direito de reunião e/ou, ainda, se é compatível com as supostas margens de regulamentação fornecidas pelo texto do art. $5^{\circ}$, XVI, da Constituição. A resposta, em um primeiro olhar, tende a ser negativa.

Ainda que não trate especificamente do texto constitucional brasileiro, essa é, também, a posição estampada por cinco organismos internacionais na Declaração Conjunta sobre o Direito à Liberdade de Reunião Pacífica e Governança Democrática. O documento, de 9 de dezembro de 2020, manifesta, nos "considerandos", a preocupação com as "numerosas medidas restritivas tomadas por governos sob o pretexto de conter e parar a pandemia de covid-19 sem levar em consideração o impacto negativo sobre os direitos á liberdade de reunião pacífica e de associação" e com a adoção de leis e regulamentos restritivos, "notadamente de proibições generalizadas" ao exercício do direito9.

9 Tradução dos autores. No original, em francês: "Lançant l'alarme concernant les nombreuses mesures restrictives prises par les gouvernements sous pretexte de contenir et d'enrayer la pandémie de COVID-19 sans tenir compte de leur impact négatif sur les droits à la liberté de réunion pacifique et d'association [...] Exprimant également une inquietude quant à l'adoption de lois et règlements 
Entre os princípios gerais da declaração, está a ideia de que não há incompatibilidade entre o exercício do direito de reunião pacífica e os objetivos de proteção da saúde, da segurança e da ordem pública.

As situações de crise, inclusas as urgências de saúde pública, não podem, em qualquer caso, ser utilizadas como pretexto para violar os direitos aplicáveis e impor restrições indevidas às liberdades públicas. No particular, as proibições generalizadas de reunião são suscetíveis de constituir uma violação inútil e desproporcional do direito, mesmo nessas situações de urgência ${ }^{10}$. (ONU et al, 2020)

Menos de duas semanas após aquela declaração, o Uruguai publicou lei que suspendeu, por 60 dias, prorrogáveis por mais 30, "as aglomerações de pessoas que gerem um notório risco sanitário”, entendendo-se como tais "a concentração, permanência ou circulação de pessoas em espaços públicos ou privados de uso públicos em que não se respeitem as medidas de distanciamento social sanitário, nem se utilizem os elementos de proteção pessoal adequados" (URUGUAI, 2020). Por outro lado, em janeiro de 2021, o Conselho de Estado da França limitou a eficácia de dois dispositivos de decreto emergencial que impunha restrições a reuniões em geral, estabelecendo serem inaplicáveis a manifestações em vias públicas ou locais abertos ao público contemplados pelo Código de Segurança Nacional (FRANÇA, 2021).

A peculiaridade brasileira é que a maioria dos projetos de lei apresentados até junho de 2020, com aptidão para regulamentar ou afetar o direito de reunião no país, nem mesmo envolve toda essa discussão, já que não encontra justificativa no cenário pandêmico, mas, sim, em embates político-ideológicos.

imposant des restrictions indues, notamment des interdictions générales, portant sur la liberté de réunion pacifique, en particulier pendant la pandémie de COVID$19[\ldots] "$...

${ }^{10}$ Tradução dos autores. No original, em francês: "Les situations de crise, y compris les urgences de santé publique, ne peuvent em aucun cas être utilisées comme pretexte pour contrevenir aux droits applicables et imposer des restrictions indues aux libertés publiques. En particulier, les interdictions générales de rassemblement sont susceptibles de constituer une violation inutile et disproportionnée du droit, même dans des situations d'urgence". 
As propostas surgidas na primeira metade da década de 2010 focavam no uso de máscaras e em crimes contra o patrimônio (influência da atuação dos chamados black blocks nos protestos da época), denotando, portanto, uma atenção às vestimentas, à identidade (contra o anonimato) e à conduta violenta dos manifestantes.

As atuais iniciativas legislativas, por outro lado, concentram-se na pauta dos atos, como os ataques à separação dos Poderes e ao funcionamento do Congresso e do Supremo Tribunal Federal, e/ou na identificação/categorização de seus participantes (por exemplo, daqueles que se denominam "antifas"). Mantêm-se o apelo e o apego ao direito penal e à tentativa de criminalização, porém, desta vez, algumas proposições flertam com uma espécie de "delito de opinião". Curiosamente, graças ao fato de tais propostas advirem de espectros político-ideológicos antagônicos, torna-se mais fácil constatar os riscos que representam, já que qualquer cidadão alinhado a um desses campos tenderá a sofrer o receio de que prevaleça a vontade dos seus opositores.

O êxito desses projetos encontra óbices em parte da doutrina. Dias e De Laurentiis (2014, p. 655), por exemplo, entendem que o exercício da liberdade de reunião é mecanismo de controle contra os abusos estatais e de proteção a minorias, ao pluralismo público e à própria democracia e, por isso, não deve estar sujeito a restrições de pautas.

De qualquer forma, a nosso ver, o Estado não deveria proibir uma reunião com o propósito de modificar uma lei criminalizadora de certa conduta, por mais que alguns comportamentos sejam fortemente reprováveis. [...] Como já mencionamos, citando Dworkin, nem a maioria dos cidadãos nem o governante tem o direito de decidir o que estamos aptos a ouvir. Isso seria infantilizar a população e os próprios governantes, que não teriam capacidade de, ouvindo opiniões, decidir o que é certo ou errado (DIAS; DE LAURENTIIS, 2014, p. 656) 
Pela mesma trilha, Dimoulis e Lunardi (2016, p. 173) rechaçam a corrente doutrinária que vislumbra, na licitude, um dos requisitos do direito de reunião. Os autores afirmam que tal concepção é equivocada porque não encontra lugar no texto do inciso XVI, do art. $5^{\circ}$, da Constituição (ao contrário do que ocorre no inciso XVII, referente às associações). Além disso, destacam que "qualquer avaliação da licitude estaria carregada de subjetivismo, sendo de duvidosa constitucionalidade”, o que impede a proibição preventiva de reunião em função de "suspeitas de ilicitude".

De igual modo, a jurisprudência do STF, ao garantir o direito à realização da Marcha da Maconha, na ADPF 187 e na ADI 4.274/DF, e de recentes protestos contra a Corte, na MC 8830/DF, também parece sugerir a declaração de inconstitucionalidade de eventuais leis naquele sentido.

Por outro lado, o inquérito acerca dos chamados atos antidemocráticos pode ser interpretado como um sinal trocado, já que a investigação recai justamente sobre manifestações perpetradas por grupos específicos, defensores de determinadas bandeiras. A dúvida quanto à legalidade foi posta, nesses casos, mais em relação ao conteúdo do que à forma dos protestos. Não se pode, entretanto, perder de vista algumas peculiaridades, como o possível envolvimento direto ou financiamento, por agentes públicos e políticos, de movimentos que reelaboram os sentidos do art. $1^{\mathrm{o}}$, parágrafo único, e do art. 142, da Constituição, para, em nome de uma suposta democracia (“todo o poder emana do povo..."), defender pautas como intervenção militar e fechamento do STF e do Congresso.

A eventual atuação daqueles agentes tem repercussões significativas, incluindo a configuração de crime de responsabilidade, à luz do art. 85, da Constituição de 1988, e da Lei no 1079/1950. Resta saber se o conteúdo do discurso propalado por aqueles movimentos será suficiente, também, para que se reconheça a ilegalidade (ou inconstitucionalidade) das manifestações em si. A conferir. 


\section{CONSIDERAÇÕES FINAIS}

A proliferação de manifestações públicas em um cenário de pandemia e de contraindicações a aglomerações poderia, em tese, ter mobilizado o Legislativo para restringir o exercício do direito de reunião. Disso, justifica-se a hipótese adotada no princípio desta pesquisa, no sentido de que a crise sanitária iniciada em março de 2020 motivaria tentativas de regulamentar aquela liberdade, assegurada pelo art. $5^{\circ}$, XVI, da Constituição de 1988.

Essa hipótese, porém, não se confirmou. Os riscos representados pelas aglomerações em manifestações públicas serviram como justificativas para algumas decisões judiciais e decretos do Poder Executivo, nos âmbitos estadual e municipal. Não figuraram, porém, como motivos relevantes na atuação do Legislativo federal.

Com isso, não se está a afirmar que os legisladores permaneceram inertes ou indiferentes àquelas manifestações públicas. Pelo contrário. A partir da consulta nos sítios das duas casas do Legislativo, observou-se que, no segundo trimestre de 2020, os deputados federais apresentaram dez projetos de lei voltados a regulamentar ou restringir o exercício do direito de reunião no país, o qual, por ora, se encontra previsto apenas em nível constitucional.

Da análise das justificações daqueles projetos, porém, concluise que a aparente incompatibilidade entre a pandemia de covid-19 e as aglomerações características das manifestações públicas ocupou um papel secundário na preocupação dos legisladores.

A maioria das propostas de regulamentação do direito de reunião reflete, na realidade, a orientação político-ideológica dos seus autores, servindo como pretensa resposta ou reação estatal contra as manifestações públicas realizadas por grupos contrários. Essa conclusão decorre das justificações dos projetos, frequentemente voltadas a ataques contra os opositores - ainda que, em algumas, a pandemia seja utilizada como fundamento de reforço. 
Contudo, advém também da coincidência entre a sequência de apresentação das propostas e a cronologia das mobilizações de rua no país. Enquanto apoiadores do governo federal monopolizavam as manifestações públicas, os deputados federais de oposição respondiam por todos os projetos de lei voltados à regulamentação ou restrição do direito de reunião. Em um segundo momento, com o início das manifestações contrárias ao presidente Jair Bolsonaro, os legisladores alinhados a sua gestão tomaram a dianteira na apresentação de proposições com aquele mesmo objetivo.

Nesses projetos, verifica-se a busca por respostas no direito penal contra os supostos excessos ou abusos no exercício do direito de reunião, bem como a tendência de tipificação de manifestantes como terroristas e de responsabilização de agentes políticos pela adoção de medidas restritivas ao exercício daquela liberdade, mesmo em estado de calamidade pública.

Apesar da profusão de projetos ligados ao direito de reunião nos primeiros meses da pandemia de covid-19, não há como prever se algum deles obterá êxito e se transformará em lei, tampouco se, alcançando tal status, subsistirá a um eventual controle de constitucionalidade. Em um primeiro olhar, considerando o histórico do STF quanto à amplitude da liberdade de reunião, aposta-se que não. Contudo, parece arriscado colocar todas as fichas em jogo, diante do desenrolar do inquérito sobre os chamados atos antidemocráticos e das aposentadorias dos dois ministros com posição mais contundente contra as limitações ao art. $5^{\circ}$, XVI, da Constituição (Ayres Britto, em novembro de 2012, e Celso de Mello, em novembro de 2020 - este último, substituído por Nunes Marques, já indicado pelo presidente Jair Bolsonaro).

Data de Submissão: 30/07/2020

Data de Aprovação: 10/05/2021 
Processo de Avaliação: double blind peer review

Editor Geral: Jailton Macena de Araújo

Editor de Área: Jailton Macena de Araújo

Assistente Editorial: Tamisa Rubia Santos do Nascimento Silva

\section{REFERÊNCIAS}

ALEMANHA. Tribunal Constitucional Alemão,

Bundesverfassungsgericht [2020a]. BVerfG 1 BvR 828/20. 14 abr. 2020. Disponível em:

https://www.bundesverfassungsgericht.de/SharedDocs/Entscheidun gen/DE/2020/04/rk20200415_1bvro82820.html. Acesso em: 25

jun. 2020

ALEMANHA. Tribunal Constitucional Alemão, Bundesverfassungsgericht [2020b]. BVerfG 1 BvQ 37/20. 17 abr. 2020. Disponível em:

https://www.bundesverfassungsgericht.de/SharedDocs/Entscheidun gen/DE/2020/04/qk20200417_1bvq003720.html. Acesso em: 25 jun. 2020

AMORIM, Felipe; BORGES, Stella. Ato contra STF e pró-intervenção tem Bolsonaro com criança e uso de cavalo. UOL. Reportagem, 31 mai 2020. Disponível em:

https://noticias.uol.com.br/politica/ultimas-

noticias/2020/05/31/protestos-brasilia-31-de-maio.htm. Acesso em: 25 jun. 2020.

ARAÚJO, Tiago Cisneiros Barbosa de. O Direito de reunião no Brasil a partir das manifestações da década de 2010:

(im)possibilidades, riscos e vantagens da regulamentação infraconstitucional. 2017. Trabalho de conclusão de curso (Bacharelado em Direito) - Universidade Federal de Pernambuco, Recife, 2017. Disponível em:

https://repositorio.ufpe.br/handle/123456789/21679. Acesso em: 30 jun. 2020

BATISTA JR., João. Protesto contra Bolsonaro tem 112 pessoas detidas por aglomeração em Belém. Veja Online, 07 jun. 2020. Reportagem. Disponível em:

https://veja.abril.com.br/politica/protesto-contra-bolsonaro-tem112-pessoas-detidas-por-aglomeracao-em-belem/. Acesso em: 20 jun. 2020

BERGAMO, Monica. Doria descarta proibir manifestações por causa de coronavírus. Folha de S. Paulo, 11 mar. 2020. Reportagem. Disponível em:

https://www1.folha.uol.com.br/colunas/monicabergamo/2020/o3/d 
oria-descarta-proibir-manifestacoes-por-causa-decoronavirus.shtml. Acesso em: 18 jun. 2020

BOEHM, Camila. Justiça paulista proíbe manifestações simultâneas na Avenida Paulista. Agência Brasil (EBC), 19 jun. 2020. Disponível em: https://agenciabrasil.ebc.com.br/justica/noticia/2020-06/justicapaulista-proibe-manifestacoes-simultaneas-na-avenida-paulista. Acesso em: 20 jun. 2020

BRASIL. Câmara dos Deputados. Projeto de Lei (PL) 1932/2020. Altera, temporariamente, a permissão de manifestações públicas, atos e demais aglomerações de pessoas enquanto estiver em vigência o Decreto Legislativo $\mathrm{n}^{\mathrm{O}} 60$ de 20 de março de 2020. Autor: Alexandre Frota (PSDB), 15 abr. 2020 [2020c]. Disponível em: https://www.camara.leg.br/proposicoesWeb/prop_mostrarintegra?c odteor $=1882216 \&$ filename $=P L+1932 / 2020$. Acesso em: 15 jun. 2020

BRASIL. Câmara dos Deputados. Projeto de Lei (PL) 2387/2020. Altera a Lei $\mathrm{n}^{\circ}$ 1.802, de 1953, que define os crimes contra o Estado e a Ordem Política e Social. Autor: André Figueiredo (PDT), 04 mai. 2020 [2020d]. Disponível em:

https://www.camara.leg.br/proposicoesWeb/prop_mostrarintegra;js essionid=3FC94C79437E81B7A94B299F74419489.proposicoesWebE xterno1 codteor $=1889779 \&$ filename $=P L+2387 / 2020$. Acesso em: 15 jun. 2020

\section{BRASIL. Câmara dos Deputados. Projeto de Lei (PL)}

2464/2020. Altera a Lei $n^{0} 7.170$, de 14 de dezembro de 1986, que "Define os crimes contra a segurança nacional, a ordem política e social, estabelece seu processo e julgamento e dá outras providências”. Autor: André Figueiredo (PDT), 07 mai. 2020 [2020e]. Disponível em:

https://www.camara.leg.br/proposicoesWeb/prop_mostrarintegra?c odteor $=1891257 \&$ filename $=P L+2464 / 2020$. Acesso em: 15 jun .2020

BRASIL. Câmara dos Deputados. Projeto de Lei (PL) 2917/2020. Altera a Lei $\mathrm{n}^{0}$ 1.079, de 10 de abril de 1950, que define os crimes de responsabilidade e regula o respectivo processo de julgamento. Autor: Guilherme Derrite (PP), 26 mai. 2020 [2020f]. Disponível em: https://www.camara.leg.br/proposicoesWeb/prop_mostrarintegra?c odteor $=1897883 \&$ filename $=P L+2917 / 2020$. Acesso em: 16 jun. 2020

\section{BRASIL. Câmara dos Deputados. Projeto de Lei (PL)}

2996/2020. Acrescenta dispositivos à Lei $n^{0} 13.869$, de 5 de setembro de 2019, à Lei no 1.079, de 10 de abril de 1950, ao DecretoLei $\mathrm{n}^{0}$ 201, de 27 de fevereiro de 1967 e à Lei ${ }^{0}$ 13.979, de 6 de fevereiro de 2020, para caracterizar como crime de abuso de autoridade e como crime de responsabilidade a violação de direitos individuais constitucionais durante tempos de paz, impedindo a 
liberdade de locomoção e o exercício de outras garantias. Autores: Damasco (PSC), Bia Kicis (PSL), Carla Zambelli (PSL), Hélio Lopes (PSL) e outros (PSC, PSL e PL), 29 mai. 2020 [2020g]. Disponível em:

https://www.camara.leg.br/proposicoesWeb/prop_mostrarintegra?c odteor $=1899215 \&$ filename $=P L+2996 / 2020$. Acesso em: 16 jun. 2020

BRASIL. Câmara dos Deputados. Projeto de Lei (PL) 3019/2020. Altera a Lei Antiterrorismo $n^{0}$ 13.260, de 16 de março de 2016, a fim de tipificar os grupos "antifas" (antifascitas) como organizações terroristas. Autor: Daniel Silveira (PSL), 01 jun. 2020 [2020h]. Disponível em:

https://www.camara.leg.br/proposicoesWeb/prop_mostrarintegra?c odteor $=1899405 \&$ filename $=P L+3019 / 2020$. Acesso em: 16 jun. 2020

BRASIL. Câmara dos Deputados. Projeto de Lei (PL)

3083/2020. Dá nova redação ao Art. $2^{\circ}$ e ao respectivo $\S 2^{\circ}$, da Lei 13.260 de 16 de março de 2016, que disciplina o terrorismo. Autor: Carlos Jordy (PSL), 02 jun. 2020 [2020i]. Disponível em: https://www.camara.leg.br/proposicoesWeb/prop_mostrarintegra?c odteor $=1900113 \&$ filename $=\mathrm{PL}+3083 / 2020$. Acesso em: 16 jun. 2020

BRASIL. Câmara dos Deputados. Projeto de Lei (PL) 3116/2020. Aprimora o tratamento penal do terrorismo, alterando a Lei $\mathrm{n}^{\mathrm{o}}$ 13.260, de 16 de março de 2016. Autor: Luiz Philippe de Orleans e Bragança (PSL), o3 jun. 2020 [2020j]. Disponível em: https://www.camara.leg.br/proposicoesWeb/prop_mostrarintegra?c odteor $=1900601 \&$ filename $=\mathrm{PL}+3116 / 2020$. Acesso em: 20 jun. 2020

BRASIL. Câmara dos Deputados. Projeto de Lei (PL)

3226/2020. Altera a Lei $n^{0} 7.170$, de 14 de dezembro de 1983, que "define os crimes contra a segurança nacional, a ordem política e social, estabelece seu processo e julgamento e dá outras providências" e a Lei $\mathrm{n}^{0} 13.260$, de 16 de março de 2016, que "regulamenta o disposto no inciso XLIII do art. $5^{\circ}$ da Constituição Federal, disciplinando o terrorismo, tratando de disposições investigatórias e processuais e reformulando o conceito de organização terrorista; e altera as Leis ns. 7.960, de 21 de dezembro de 1989, e 12.850, de 2 de agosto de 2013. Autor: Nereu Crispim (PSL), 09 jun. 2020 [2020k]. Disponível em:

https://www.camara.leg.br/proposicoesWeb/prop_mostrarintegra?c odteor $=1902615 \&$ filename $=\mathrm{PL}+3226 / 2020$. Acesso em: 20 jun. 2020

BRASIL. Câmara dos Deputados. Projeto de Lei (PL) 3319/2020. Revoga o $\S 2^{\circ}$ do art. $2^{\circ}$ e altera a redação do caput do art. $2^{\circ}$ da Lei $\mathrm{n}^{0} 13.260$, de 16 de março de 2016, que regulamenta o disposto no inciso XLIII do art. $5^{\circ}$ da Constituição Federal, disciplinando o terrorismo, tratando de disposições investigatórias e processuais e reformulando o conceito de organização terrorista; e altera as Leis $\mathrm{n}^{\mathrm{o}}$ 
7.960, de 21 de dezembro de1989, e 12.850, de 2 de agosto de 2013,para inserir o caráter político entre as razões motivadoras do terrorismo. Autor: Vitor Hugo (PSL), 15 jun. 2020 [2020l].

Disponível em:

https://www.camara.leg.br/proposicoesWeb/prop_mostrarintegra;js essionid=EC57ACD840DDE7088770BECA6F67CCCB.proposicoesW ebExterno2? codteor $=1903951 \&$ filename $=P L+3319 / 2020$. Acesso em: 20 jun. 2020

BRASIL [Constituição (1824)]. Constituição Política do Império do Brazil. Rio de Janeiro, RJ: Presidência da República. Disponível em:

http://www.planalto.gov.br/ccivil_o3/Constituicao/Constituicao24. htm. Acesso em: 08 jun. 2020

BRASIL [Constituição (1891)] Constituição da República dos Estados Unidos do Brasil. Rio de Janeiro, RJ: Presidência da República. Disponível em: http://www.planalto.gov.br/ccivil_03/Constituicao/Constituicao91.h tm. Acesso em: o8 jun. 2020

BRASIL [Constituição (1934)] Constituição da República dos Estados Unidos do Brasil. Rio de Janeiro, RJ: Presidência da República. Disponível em: http://www.planalto.gov.br/ccivil_o3/constituicao/constituicao34.h tm. Acesso em: 08 jun. 2020

BRASIL [Constituição (1937)] Constituição dos Estados Unidos do Brasil. Rio de Janeiro, RJ: Presidência da República. Disponível em:

http://www.planalto.gov.br/ccivil_o3/Constituicao/Constituicao37. htm. Acesso em: o8 jun. 2020

BRASIL [Constituição (1946)] Constituição dos Estados Unidos do Brasil. Rio de Janeiro, RJ: Presidência da República. Disponível em:

http://www.planalto.gov.br/ccivil_o3/constituicao/constituicao46.h tm. Acesso em: 08 jun. 2020

BRASIL. [Constituição (1967)] Constituição da República

Federativa do Brasil. Brasília, DF: Presidência da República.

Disponível em:

http://www.planalto.gov.br/ccivil_03/Constituicao/Constituicao67. htm. Acesso em: 08 jun. 2020

BRASIL [Constituição (1988)]. Constituição da República

Federativa do Brasil. Brasília, DF: Presidência da República.

Disponível em:

http://www.planalto.gov.br/ccivil_o3/constituicao/constituicao.htm . Acesso em: 08 jun. 2020 
BRASIL. Lei no 1.079, de 25 de outubro de 1950. Dispõe sobre o direito de reunião. Rio de Janeiro: Congresso Nacional [2020]. Disponível em: http://www.planalto.gov.br/ccivil_03/leis/19501969/L1207.htm. Acesso em: 10 jun. 2020

BRASIL. Supremo Tribunal Federal [Pleno]. Ação Direta de Inconstitucionalidade 4274/DF. Requerente: Procurador-Geral da República. Interessado: Presidente da República e Congresso Nacional. Relator: Min. Ayres Britto, 23 nov. 2011 [2011b]. Disponível em: http://redir.stf.jus.br/paginadorpub/paginador.jsp?docTP=TP\&docI $\mathrm{D}=1955301$. Acesso em: 22 jun. 2020

BRASIL. Supremo Tribunal Federal [Pleno]. Ação Direta de Inconstitucionalidade 1.969-4/DF. Requerentes: Partido dos Trabalhadores, Confederação Nacional dos Trabalhadores da Agricultura e Central Única dos Trabalhadores. Requerido: Governador do Distrito Federal. Relator: Min. Ricardo Lewandowski, 28 jun. 2007. Disponível em:

http://redir.stf.jus.br/paginadorpub/paginador.jsp?docTP=AC\&docI $\mathrm{D}=484308$. Acesso em: 25 jun. 2020

BRASIL. Supremo Tribunal Federal [Pleno]. Arguição de Descumprimento de Preceito Fundamental 187/DF. Requerente: Procurador-Geral da República. Interessado: Presidente da República. Relator: Min. Celso de Mello, 15 jun. 2011 [2011a]. Disponível em:

http://redir.stf.jus.br/paginadorpub/paginador.jsp?docTP=TP\&docI $\mathrm{D}=5956195$. Acesso em: 22 jun. 2020.

BRASIL. Supremo Tribunal Federal [decisão monocrática]. Medida Cautelar na Petição 8.830/DF. Requerente: Enio José Verri.

Requerido: Paulo Felipe. Relator: Min. Celso de Mello, o7 mai. 2020 [2020a]. Disponível em:

http://www.stf.jus.br/arquivo/cms/noticiaNoticiaStf/anexo/Pet883 odecisao.pdf. Acesso em: 25 jun. 2020

BRASIL. Supremo Tribunal Federal [Pleno]. Recurso

Extraordinário com Agravo 905.149/RJ. Recorrente: Diretório Regional do Partido da República. Recorrido: Assembleia Legislativa do Estado do Rio de Janeiro. Relator: Min. Luís Roberto Barroso, 25 ago. 2016. Disponível em:

https://jurisprudencia.stf.jus.br/pages/search/repercussaogeral8822/false. Acesso em: 25 jun. 2020

BRASIL. Procuradoria Geral da República. Recurso

Extraordinário com Agravo 905.149/RJ. Parecer pelo provimento do recurso extraordinário com fixação das teses sugerida. Procurador-Geral da República: Augusto Aras, 31 mar. 2020 
[2020b]. Disponível em:

http://portal.stf.jus.br/processos/downloadPeca.asp?id=1534279782 7\&ext=.pdf. Acesso em: 25 jun. 2020.

CAVALCANTI, Henrique Breda; NETO, Edgard Freitas;

CERQUEIRA, Nelson. Toque de Recolher e Lockdown: a Mutação Inconstitucional Promovidas pelas Autoridades Locais no Combate à Covid-19 no Brasil. Revista Prim@ Facie, João Pessoa, v. 19, n. 42, p. 463-489, set-dez. 2020. Disponível em:

https://periodicos.ufpb.br/ojs2/index.php/primafacie/issue/view/2 501. Acesso em: 14 fev. 2021

CORAO, Carlos Ayala. Retos de la Pandemia del Covid-19 para el Estado de Derecho, la Democracia y los Derechos Humanos. Max Planck Institute for Comparatibe Public Law \& Internation Law, n. 17-2020. Disponível em: http://dx.doi.org/10.2139/ssrn.3596040 . Acesso em: 12 fev. 2021

CORREIO BRAZILIENSE. Justiça proíbe manifestação na Avenida Paulista neste domingo. Correio Braziliense, 06 jun. 2020.

Reportagem. Disponível em:

https://www.correiobraziliense.com.br/app/noticia/brasil/2020/o6 /o6/interna-brasil,861641/justica-proibe-manifestacao-na-avenidapaulista-neste-domingo.shtml. Acesso em: 19 jun. 2020

DIAS, Roberto; DE LAURENTIIS, Lucas. Liberdade de reunião e democracia: reflexões a partir das experiências brasileiras e alemãs. Revista Brasileira de Estudos Constitucionais (RBEC), ano 8, n. 30, p. 649-669, Belo Horizonte, Set-dez. 2014.

DIMOULIS, Dimitri; LUNARDI, Soraya Regina Gasparetto. O valor constitucional dos protestos populares: o fim dos "inocentes do Leblon”. Revista Direitos Humanos Fundamentais, ano 16, n. 2, p. 167-178, Osasco, Jul-dez. 2016.

DISTRITO FEDERAL. Decreto no 4o.884, de 16 de junho de 2020. Determina o fechamento da Esplanada dos Ministérios para veículos e pedestres. Brasília, Governo do Distrito Federal [2020]. Disponível em:

http://www.sinj.df.gov.br/sinj/Norma/ab5be697b76c4c659cob7f941 c0824ac/Decreto_40884_16_06_2020.html. Acesso em: 20 jun. 2020

DUQUE, Marcelo Schenk; NASCIMENTO, Isabela Moreira Antunes do. O princípio da proporcionalidade à luz da Teoria dos Limites dos Limites: critérios de análise de restrições a direitos fundamentais. Revista Estudos Institucionais, v. 4, n. 2, pp. 949-968, Jul-dez. 2018. Disponível em:

https://www.estudosinstitucionais.com/REI/article/download/308/ 290. Acesso em: 04 jul. 2020 
ESTADO DE MINAS. Justiça proíbe manifestações e manda processar organizadores em três estados. Estado de Minas, 30 mar. 2020. Reportagem. Disponível em:

https://www.em.com.br/app/noticia/politica/2020/o3/30/interna_ politica,1133862/justica-proibe-manifestacoes-e-manda-processarorganizadores-em-tres-e.shtml. Acesso em: 19 jun. 2020

FERNANDES, Talita; PUPO, Fábio. Bolsonaro volta a apoiar ato contra STF e Congresso e diz que Forças Armadas estão 'ao lado do povo'. Folha de S. Paulo, o3 mai 2020. Reportagem. Disponível em: https://www1.folha.uol.com.br/poder/2020/05/ato-probolsonaro-em-brasilia-tem-carreata-e-xingamentos-a-moro-stf-econgresso.shtml. Acesso em: 25 jun. 2020

FIALHO, Arthur Monteiro Lins; RIBEIRO, Luiz Filipe de Araújo. A liberdade de reunião e a exigência de prévio aviso à autoridade competente. Revista do CEPEJ, v. 20, p. 61-87, Salvador, Jul-dez. 2017. Disponível em: https://portalseer.ufba.br/index.php/CEPEJ/article/download/2715 7/16356. Acesso em: 28 jun. 2020

FRANÇA. Conselho de Estado [10 ${ }^{\mathrm{a}}$ e $9^{\mathrm{a}}$ Câmaras Reunidas].

Décision n. 441265, lecture du 15 janvier 2021.

ECLI:FR:CECHR:2021:441265.20210115. 10 a 9 $^{\text {a }}$ Câmaras Reunidas. Relator: M. Laurent Roulaud. Disponível em: https://www.conseil-etat.fr/fr/arianeweb/CE/decision/2021-0115/441265. Acesso em: 15 fev. 2021

FRITZ, Karina Nunes. Tribunal Constitucional alemão garante direito de manifestação mesmo em tempos de coronavírus. Portal Migalhas, 22 abr. 2020. Coluna German Report. Disponível em: https://www.migalhas.com.br/coluna/germanreport/325145/tribunal-constitucional-alemao-garante-direito-demanifestacao-mesmo-em-tempos-de-coronavirus. Acesso em: 25 jun. 2020

G1. Bolsonaro discursa em Brasília para manifestantes que pediam intervenção militar. Portal G1, 19 abr 2020 [2020a]. Reportagem. Disponível em:

https://g1.globo.com/politica/noticia/2020/o4/19/bolsonarodiscursa-em-manifestacao-em-brasilia-que-defendeu-intervencaomilitar.ghtml. Acesso em: 25 jun. 2020

G1. Casos de coronavírus e número de mortes no Brasil em 31 de maio. G1, 31 mai 2020 [2020b]. Reportagem. Disponível em: https://g1.globo.com/bemestar/coronavirus/noticia/2020/05/31/ca sos-de-coronavirus-e-numero-de-mortes-no-brasil-em-31-demaio.ghtml. Acesso em: 08 jun. 2020. 
G1. Entenda inquérito sobre manifestações antidemocráticas. G1, 15 jun. 2020 [2020c]. Reportagem. Disponível em:

https://g1.globo.com/politica/noticia/2020/o6/15/entendainquerito-do-stf-sobre-manifestacoes-antidemocraticas.ghtml. Acesso em: 25 jun. 2020

GAZETA DO POVO. Justiça do Rio proíbe carreata para pedir o fim da quarentena do coronavírus. Gazeta do Povo, 28 mar. 2020. Reportagem. Disponível em: https://www.gazetadopovo.com.br/republica/breves/justica-rioproibe-carreata-pelo-fim-da-quarentena-coronavirus/. Acesso em: 19 jun. 2020

GONÇALVES, Luiz Alcione. O direito fundamental de reunião e a liberdade de circulação. 2015. Dissertação (mestrado em direito) - Universidade Federal da Bahia da Bahia, Salvador, 2015. Disponível em:

https://repositorio.ufba.br/ri/bitstream/ri/17744/1/LUIZ\%20ALCIO NE\%2OGON\%C3\%87ALVES\%20-

\%2ODISSERTA\%C3\%87\%C3\%83O.pdf. Acesso em: 25 jun. 2020

GUSMÃO, Hugo César Araújo de; GUIMARÃES, Diego Fernandes. A Liberdade de Reunião sob Cuidados Intensivos. Revista de Direito Público, Brasília, v. 17, n. 94, Dossiê Especial Covid-19, v. 1, p. 100118, jul/ago. 2020. Disponível em:

https://www.portaldeperiodicos.idp.edu.br/direitopublico/article/vi ew/4491/Gusm\%C3\%A30\%3B\%20Guimar\%C3\%A3es\%2C\%202020. Acesso em: 13 fev. 2021

MARTINS, Leonardo. Direito fundamental à liberdade de reunião e controle de constitucionalidade de leis penais e de sua interpretação e aplicação: contribuição para o direito de reunião como sub-ramo autônomo do direito administrativo. Espaço Jurídico Journal of Law (EJJL), v. 18, n. 2, p. 433-490, Joaçaba, Mai-ago. 2017. Disponível em: https://dialnet.unirioja.es/descarga/articulo/6179696.pdf. Acesso em: 15 jul. 2020

MORAES, Alexandre de. Direito de reunião nas sociedades democráticas. In: LOUREIRO, Francisco Eduardo; PRETTO, Renato Siqueira de; KIM, Richard Pae (coord.). A vida dos direitos nos 30 anos da Constituição Federal. São Paulo: Escola Paulista da Magistratura (EPM), 2019. p. 35-46.

MORAIS, Márcio Eduardo Senra Nogueira Pedrosa; SILVA; Luciana Andréa França. Definindo os limites constitucionais da liberdade de manifestação de pensamento: a polêmica acerca da proibição do uso de máscaras em manifestações. Revista Brasileira de Filosofia do Direito, v. 2, n. 2, p. 37-52, Curitiba, Jul-dez. 2016. Disponível em: 
https://indexlaw.org/index.php/filosofiadireito/article/view/1468/1 926. Acesso em: 20 jun. 2020

NELSON, Rocco Antonio Rangel Rosso; FERNANDES, Rafael Laffitte; NELSON, Isabel Cristina Amaral de Sousa Rosso. Conflito federativo e o covid-19: ponderações sobre a (in)constitucionalidade dos decretos estaduais e municipais. Revista Jurídica LusoBrasileira - RJLB, ano 6, n. 4, p. 2.551-2.585, 2020. Disponível em:

https://www.cidp.pt/revistas/rjlb/2020/4/2020_04_2551_2585.pd f. Acesso em: 13 fev. 2021

NOVELLINO, Vicente Nicola. As manifestações públicas e o papel constitucional das polícias militares. Revista do Laboratório de Estudos da Violência da UNESP, ed. 19, p. 22-39, Marília, Mai. 2017. Disponível em:

http://www2.marilia.unesp.br/revistas/index.php/levs/article/view/ 7013/4499. Acesso em: 08 jul. 2020

OEA (Organização dos Estados Americanos). Convenção Americana de Direitos Humanos (Pacto de San José da Costa Rica), 22 de novembro de 1969. Disponível em: https://www.cidh.oas.org/basicos/portugues/c.convencao_american a.htm. Acesso em: 14 fev. 2021

ONU (Organização das Nações Unidas); CIDH (Comissão Interamericana dos Direitos Humanos); RSLE (Relator Especial sobre a Liberdade de Expressão); ACHPR (Comissão Africana de Direitos Humanos e dos Povos); ODIHR (Escritório das Instituições Democráticas e Direitos dos Homens da OSCE). Déclaration Conjointe Sur le Droit à la Liberté de Réunion Pacifique et la Gouvernance Démocratique, 2020. Disponível em: https://www.ohchr.org/Documents/Issues/FAssociation/jointdeclaration-democratic-governance/declaration-fr.pdf. Acesso em: 14 fev. 2021

PARÁ. Decreto no 609, de 16 de abril de 2020. Dispõe sobre as medidas de enfrentamento, no âmbito do Estado do Pará, à pandemia do corona vírus COVID-19. Belém: Governo do Estado do Pará [2020]. Disponível em:

https://www.sistemas.pa.gov.br/sisleis/legislacao/5444. Acesso em: 15 jun. 2020

PARANÁPORTAL. Sob multa de até R $\$ 10$ mil, Justiça proíbe manifestações em Curitiba por uma semana. Paranáportal, 15 jun. 2020. Reportagem. Disponível em: https://paranaportal.uol.com.br/cidades/sob-multa-de-ate-r-10-miljustica-proibe-manifestacoes-em-curitiba-por-uma-semana/. Acesso em: 19 jun. 2020 
PORTUGAL [Constituição (1976)] Constituição da República Portuguesa. Disponível em: https://dre.pt/constituicao-darepublica-portuguesa. Acesso em: 10 jun. 2020

SAUNDERS, Joss. La Covid-19 y los Derechos Humanos: Obligaciones de los Estados y responsabilidades de las empresas em la respuesta a la pandemia. Documento de Debate de Oxfam, 2020. Disponível em:

https://oxfamilibrary.openrepository.com/bitstream/handle/10546/ 621037/dp-covid-19-human-rights-principles-070820-advancees.pdf;jsessionid=CFFEEFE81A1A89888546E4DBAD9C5Bo8?seque nce $=5$. Acesso em: 15 fev. 2021

SARLET, Ingo Wolfgang; NETO, Jayme Weingartner. Liberdade de expressão: algumas ponderações em matéria penal à luz da Constituição Federal do Brasil. Espaço Jurídico Journal of Law (EJJL), v. 18, n. 3, p. 637-66o, Joaçaba, Set-dez. 2017. Disponível em:

https://portalperiodicos.unoesc.edu.br/espacojuridico/article/view/ 16256. Acesso em: 20 jun. 2020

SILVA, José Afonso da. Aplicabilidade das normas constitucionais. Revista Pensar de Ciências Jurídicas, v. 2, n. 1, p. 7-22, Fortaleza, 1993. Disponível em: https://periodicos.unifor.br/rpen/article/view/2343. Acesso em: 28 jun. 2020

SILVA, Virgílio Afonso da. O conteúdo essencial dos direitos fundamentais e a eficácia das normas constitucionais. RDE: Revista de Direito do Estado, Rio de Janeiro, v. 1, n. 4, p. 23-51, 2006.

SIMÃO, José Luiz de Almeida; RODOVALHO, Thiago. A fundamentalidade do direito à liberdade de expressão: as justificativas instrumental e constitutiva para a inclusão no catálogo dos direitos e garantias fundamentais na Constituição Federal de 1988. Cadernos do Programa de Pós-Graduação em Direito da Universidade Federal do Rio Grande do Sul, n. 1, vol. 12, Porto Alegre, 2017. Disponível em: https://seer.ufrgs.br/ppgdir/article/download/72978/43857. Acesso em: 20 jun. 2020

SOUSA, António Francisco de. Liberdade de reunião e de manifestação no Estado de direito. Revista Brasileira de Direitos Fundamentais \& Justiça, v. 6, n. 21, pp. 27-38, Out-dez. 2012. Disponível em: http://dfj.emnuvens.com.br/dfj/article/view/295. Acesso em: 28 jun. 2020

SOUZA, Carlos Aurélio Mota de. Segurança jurídica e jurisprudência: um enfoque filosófico-jurídico: súmulas 
vinculantes, Direito alternativo, auctoritas ou potestas? São Paulo: LTR, 1996.

TARUFFO, Michele. Precedente e jurisprudência. Revista de Processo (Repro), v. 199, p. 139-149. set. 2011, Trad. Teresa Arruda Alvim Wambier e André Luís Monteiro.

UOL. Justiça barra manifestações e autoriza uso de força policial em Campinas. Uol Notícias, 15 mai 2020. Reportagem. Disponível em: https://noticias.uol.com.br/saude/ultimasnoticias/redacao/2020/05/15/justica-barra-manifestacoes-eautoriza-uso-de-forca-policial-em-campinas.htm. Acesso em: o8 jun. 2020

URUGUAI. Ley n. 19932, de 21 de deciembre de 2020. Reglamentacion de los arts. 37 y 38 de la Constitución de la República. Centro de Información Oficial. Disponível em: https://www.impo.com.uy/bases/leyes/19932-2020. Acesso em: 15 fev. 2021

VALADARES, João. Líder de ato pró-Bolsonaro em PE é detido por ignorar decreto contra aglomeração. Folha de S. Paulo, 16 mar. 2020. Reportagem. Disponível em: https://www1.folha.uol.com.br/poder/2020/o3/lider-de-ato-probolsonaro-em-pe-e-detido-por-ignorar-decreto-contraaglomeracao.shtml. Acesso em: 18 jun. 2020

VEJA. Brasil tem manifestações a favor e contra Bolsonaro no Rio, SP e Brasília. Veja Online. Reportagem, 31 mai 2020. Disponível em: https://veja.abril.com.br/politica/brasil-tem-manifestacoes-a-favore-contra-bolsonaro-no-rio-sp-e-brasilia/. Acesso em: 03 jul. 2020

VILAR, Filipe. Manifestantes fazem protesto em apoio a Bolsonaro na BR 232. Diario de Pernambuco, 19 abr 2020. Reportagem. Disponível em: https://www.diariodepernambuco.com.br/noticia/politica/2020/o4 /manifestantes-fazem-protesto-em-apoio-a-bolsonaro-na-br232.html. Acesso em: 18 jun. 2020 
Public Manifestations In Pandemic Times: Covid-19's Effect On Infra-Constitutional Positivation Of Freedom Of Assembly

Tiago Cisneiros Barbosa de Araújo

\title{
Bruno Galindo
}

\begin{abstract}
This work approaches the attempts of infra-constitutional regulation of freedom of assembly in Brazil during covid-19 pandemic. It provides a situation analysis, with basis on sanitary crisis and political-ideological fights, and focus on Federal Legislative performance. The objective is to verify if coronavirus risks have motivated the submission of propositions for establishing rules or limits for the exercise of freedom of assembly. The work has grounds in qualitative research, using public data, and is divided in four parts. In first one, there is a discussion about the concept, the rules and the scope of the freedom of assembly. The second section approaches the responses given by Executive and Judiciary for public acts in the second quarter of 2020, in view of pandemic and some protests' anti-democratic content. In third section, we realize a survey and an analysis of recent legislative proposals about freedom of assembly and their reasons, to solving the problem related to covid-19's influence. Eventually, we discuss the solutions indicated by the three powers in light of the effectiveness and the content of that right, as well as the limitations to restrict it. We refute the hypothesis that covid-19 pandemic encourages attempts of freedom of assembly's infra-constitutional regulation. As a rule, legislative proposals are motivated by political-ideological issues.
\end{abstract}

Keywords: Freedom of assembly. Fundamental rights. Manifestations. Covid-19. Politics. Antifa.

DOI: https://doi.org/10.22478/ufpb.1678-2593.2021v20n43.54255

Conteúdo sob licença Creative Commons: Attribuition-NonCommercial-NoDerivative 4.o International (CC BY-NC-ND 4.0) 